tinta, Madrid: Biblioteca Nacional de España, pp. 63-84.

Kowaleski-Wallace, Elizabeth, ed. (2009), Elizabeth Smith, Compleat housewife, Chawton: Chawton House Library.

Valls i Subirá, Oriol (1982), La historia del papel en España. Siglos XVII-XVIII, Madrid: Empresa Nacional de Celulosas.

Wheaton, Barbara K. (1983), Savoring the Past. The French Kitchen and Table from 1300 to 1789 , Londres: Chato \& Windus.

\section{DOMESTICAR LA ESCRITURA PROFESIONALIZACIÓN Y MORAL BURGUESA EN LA OBRA PEDAGÓGICA DE MARÍA DEL PILAR SINUÉS (1835-1893)}

\section{ALBA GONZÁLEZ SANZ}

Universidad de Oviedo gonzalezalba.uo@uniovi.es

RESUMEN: El artículo analiza el modelo de conducta que $M^{a}$ del Pilar Sinués propone en su obra pedagógica para las mujeres de las clases medias españolas como el más conveniente por la religión y costumbres del país, en relación con el propio estatus de la escritora como mujer de letras que justifica su presencia en la esfera pública a través de la literatura de la domesticidad. Se analizan aspectos relativos a la identidad, la educación, el trabajo y la familia, así como la abierta oposición de Sinués al feminismo contemporáneo, poniendo de manifiesto las contradicciones entre vida y discurso que encarna una autora que accedió a la palabra pública y se consolidó profesionalmente a través de la difusión del estereotipo burgués del "Ángel del Hogar".

PALABRAS CLAVE: Literatura española, siglo XIX, domesticidad, feminismo, María del Pilar Sinués, educación femenina.

DOI: $2222-2222$ 


\section{TAMING WRITING. Professionalization and Bourgeois Morality in Ma-} ría del Pilar Sinués' Educational Works (1835-1893)

ABSTRACT: María del Pilar Sinués' educational works propose a role model for Spanish middle-class women that is presented as the most suitable for the nation's religion and customs. This essay examines the relationship between this proposition and Sinués' place as a female writer who asserts her presence in the public sphere through the literature of domesticity. Issues related to identity, education, labor and family, and Sinués' marked opposition to contemporary feminism are also discussed, highlighting contradictions between her life as a professional writer in the public arena and her promulgation of the bourgeois stereotype of the "Angel in the House."

KEYWORDS: Spanish Literature, 19th century, domesticity, feminism, María del Pilar Sinúes, women education.

\section{Introducción}

CC — ¡Prosa! — me gritó el mundo: — dame prosa / Y ceñiré tu sien de lauro bello / Y alfombra de oro tenderé a tus plantas; / Prosaico es este siglo y prosa quiero!- - En 1860, María del Pilar Sinués publicaba estos versos y constataba en ellos el devenir literario del siglo y, en cierta manera, la evolución que se producía entonces en la literatura escrita por mujeres en España. Pasada la década de 1840 y el momento de gran éxito de las poetas románticas, Carolina Coronado y Gertrudis Gómez de Avellaneda, aparece en escena un tipo de escritora que se define por la contradicción al sustentar su legitimidad creadora, su presencia en la esfera pública, en la defensa del papel esencial que las mujeres deben jugar en la sociedad como esposas y madres, dentro de los límites del hogar. Lo hace poblando la literatura de mediados del XIX de "Ángeles del Hogar" que, en palabras de Alda Blanco:

triunfan sobre rocambolescas adversidades, malas y ociosas mujeres, seductores desalmados y madres siniestras, establecen su virtuosa forma de ser como el ideal femenino, pintan la vida doméstica como lo naturalmente suyo y, finalmente, promueven el hogar como el espacio más apropiado para la mujer (2001: 13).

Entre todas las escritoras que sobresalieron en el "canon isabelino" (Sánchez Llama, 1999), la zaragozana María del Pilar Sinués ocupa un lugar destacado. Está considerada la primera mujer que vivió íntegramente de su trabajo como escritora en España, publicando más de un centenar de obras entre novelas, manuales pedagógicos, cuentos y poemas (Simón Palmer, 1991). A ella se le debe un texto de elocuente título, El ángel del hogar (1859), central para entender la configuración ideológica de la burguesía española con respecto al papel social reservado a las mujeres. Tradujo obras francesas y anglosajonas, participó en diversas publicaciones femeninas y, en general, disfrutó de éxito en vida, siendo de las pocas autoras del siglo cuyas obras se imprimieron hasta bien entrado el XX y que gozó, además, de gran repercusión en América Latina, donde también es posible rastrear ediciones contemporáneas de su obra.

En sus textos, especialmente en aquellos de corte pedagógico que analizan de forma directa el día a día contemporáneo, bullen el siglo XIX y la ola de cambios que para las mujeres iba a suponer tomar la palabra y pretender hacer uso de ella. La educación, el trabajo, el derecho de ciudadanía comenzaban a pelearse de forma seria. Y aunque Pilar Sinués dista mucho de ser una escritora siquiera protofeminista ${ }^{1}$, en su obra hay una constante tensión entre deber y deseo que se plasma en la progresiva apertura ideológica que la autora demuestra. Apertura, claro está, dentro de unos límites estrechos que se justifican, en último término, por la consolidación del capitalismo como motor no sólo de las economías, sino de las relaciones

${ }^{1}$ Sinués mantuvo una postura abiertamente hostil hacia las escritoras que se atrevieron a defender los derechos de las mujeres, como era el caso de Rosario de Acuña. En 1891, ya al final de su vida, Las dominicales del libre pensamiento reseñó unas palabras de la autora sobre la escritora madrileña y sobre el propio periódico, al que considera de poca importancia y sin apenas público lector: "Se nos envía de la Habana un recorte del Diario de la Marina, en el cual la señora doña María del Pilar Sinués dice, hablando de las páginas de Las dominicales del libre pensamiento, que 'apenas las lee nadie', y agrega, intentando criticar a doña Rosario de Acuña, que 'se puede ser libre-pensadora, pero no libre-escritora ni aun librehabladora"' (20-6-1891). El redactor de la nota añadía precisamente que las declaraciones de Sinués eran propias de quien estaba ejerciendo como libre-escritora y libre-habladora, incidiendo en la palmaria contradicción entre discurso y vida de la autora zaragozana. 
humanas a lo largo de los últimos años del siglo XIX en España.

A lo largo de este artículo me propongo estudiar el modelo de mujer española que defiende Pilar Sinués en relación con la manera en que ella construye su propia imagen de escritora. Es decir, me interesa la paradoja: cómo la autorrepresentación pública se sustenta y legitima en la escritura doméstica. Este proceso identitario no se da en Sinués de forma repentina o consciente: a lo largo del corpus seleccionado, se observan cambios y avances en la imagen que la escritora proyecta de sí, solidarios con los tímidos cantos a favor de la educación y el trabajo femeninos que la autora entona.

Sin duda esta paradoja podría estudiarse a través de su obra narrativa, pero dado que la carga ideológica es mayor y frontal en la que he considerado pedagógica, me ha parecido más interesante para indagar en la contradicción intrínseca a la literatura doméstica. Precisamente para conocer bien este tipo de obras, me detengo previamente en repasar su teorización en el ámbito de la teoría feminista y del hispanismo, para después estudiar cómo construye María del Pilar Sinués su imagen pública de escritora y, finalmente, el modelo de conducta que intenta imponer en las españolas de las clases medias a través de su obra de adoctrinamiento. Las conclusiones reúnen una serie de hipótesis que pretenden arrojar luz sobre una figura cuyo conservadurismo no impide que su literatura y su obra en prosa de no ficción sean determinantes en el estudio de la inclusión de las escritoras en la esfera pública, junto con las particularidades y condicionantes ideológicos de ese acceso (literatura doméstica, temáticas "femeninas", etc.).

\section{Lo doméstico como vía de acceso a la esfera pública}

El desarrollo del capitalismo y la redefinición de la burguesía como clase consumidora están en estrecha relación con tres fenómenos determinantes de la caracterización literaria del siglo XIX. Me refiero a la profesionalización de la escritura, al auge de la imprenta que consolida la prensa y la literatura por entregas, y a la entrada de las escritoras en el panorama literario. El aumento de las escritoras en el mercado y la ampliación del número de lectoras están en relación con las decenas de publicaciones $f e$ - meninas que abundan ya durante el reinado de Fernando VII. En este tipo de prensa se curtirán $\mathrm{M}^{\mathrm{a}}$ del Pilar Sinués y sus contemporáneas: publicarán artículos, poemas o novelas por entregas, también asumirán la dirección de estos proyectos, siempre sorteando unas leyes que les impiden ciertos trabajos: en lo que toca a la escritura, la Ley de Prensa de 1836 obliga a recurrir al marido o a otro hombre como "editor responsable".

No sólo escribirán en prensa destinada para mujeres: Sinués publica con regularidad y durante un amplio período de tiempo que va de 1875 a 1890 en el periódico progresista El Imparcial, aunque abordando temas relacionados con la "cuestión femenina" de una u otra forma (acceso y contenidos de la educación, posibilidad de trabajar, moral y religiosidad...) (Sánchez Llama, 1999: 278). Esta participación femenina en diversas empresas periodísticas no será ajena a los problemas que padecen las publicaciones masculinas, especialmente a la censura que bajo los gobiernos moderados es muy restrictiva.

El estudio de la irrupción de las mujeres en la literatura decimonónica ha sido abordado desde varios frentes. Por un lado, contamos con la ingente labor bibliográfica de Carmen Simón Palmer, que nos aporta los datos y el catálogo de escritoras y, por otro, con los análisis fundamentales de Susan Kirkpatrick en su libro Las románticas. Escritoras y subjetividad en España, 1835-1850. Esta última obra analiza una serie de procesos claves en la formación de una subjetividad femenina moderna que afecta a la literatura escrita por mujeres. Voy a repasar las tesis principales de esta autora para situar el discurso y la estética en la que $\mathrm{M}^{\mathrm{a}}$ del Pilar Sinués comienza a escribir.

En el siglo XVIII el sentimiento se convierte en un valor social del hombre de bien². De ahí se deriva una resignificación de la subjetividad y

${ }^{2}$ El hombre de bien se define por emplear su razón para la consecución de la felicidad pública: es un ser social. Por oposición a esto, la mujer de bien definida en el XVIII es una clara precursora del modelo de la domesticidad burguesa, ya que es un ideal construido a partir de la maternidad y del cumplimiento de las obligaciones familiares como esposa. Sólo en el tiempo libre de las tareas se le permitirá una limitada formación. Este planteamiento es claro en la segunda mitad de la centuria, a pesar de que en 1726 Feijoo escribiera su revolucionaria Defensa de las mujeres (Discurso XVI del Tomo I del Teatro crítico universal). 
de la intimidad sobre la que se articula el discurso romántico. Sin embargo, el ámbito de las emociones ha sido hasta ese momento patrimonio natural femenino, lo que situaría a las mujeres en una posición privilegiada para la literatura. En oposición a esto, la moral social en formación prefigura a las mujeres como seres sin deseo, las imposibilita para la subjetividad romántica masculina (Kirkpatrick, 1991: 20). Además, lo femenino se convierte en "el objeto de los poderes creativos, al centrar el yo creador en un deseo presuntuoso supuestamente ajeno a la mujer" (1991: 27). De este modo, las escritoras deben enfrentar la contradicción de un sistema que las considera objetos pero no sujetos, que las confina en el papel de musas.

La literatura de la domesticidad se convierte así en la única vía a través de la cual las creadoras pueden vencer la resistencia del sistema. Para Susan Kirkpatrick estaríamos ante una "tradición romántica específicamente femenina" (1991: 37), en tanto que con este ideario se ajusta una subjetividad construida desde el deseo a unas escritoras que deben definirse por carecer de él. La base sobre la que se apoya este quiebro es el nuevo poder que la sociedad burguesa confiere a las mujeres dentro del hogar, convirtiéndolas en esos ángeles que reinan en un espacio construido por oposición al mercado y en el que se enseñorean de los afectos familiares (1991: 36).

La casa puede ser vista entonces como un espacio protector para los personajes femeninos, porque genera una solidaridad entre ellos de la que está excluido el varón y en el que se valoran las especiales funciones sociales de las mujeres, tal y como propone Lou Charnon Deutsch:

The home was not just a prison (although this certainly was in a physical sense for many bad heroines), but a place where a feminine ideal of intersubjectivity could be striven for if not obtained. In this sense, the cult of domesticity fostered a kind of recognition that placed a high value on women's activities and problems. It recognized and valued the mother for her sacrifice to her children, as much as the children's sacrifice for the good of others (1994: 35).

Kirkpatrick señala que la domesticidad es la única manera de resolver este conflicto entre la subjetividad liberal y el ideal femenino. Sin embargo, hasta que esto se consolida, las escritoras pueden moverse en unos márgenes más libres para la creación. En la década de 1840 la poesía habla de una sensibilidad femenina especial que reclama su acceso a la cultura y el derecho a escribir. La reacción mayoritaria de la crítica masculina y, con ella, de todo el ámbito literario es censurar a estas escritoras al considerar que la literatura es incompatible con la virtud, ese rasgo casi metafísico sin el cual una mujer es denostada y estigmatizada en la sociedad. La respuesta de las autoras es convertir en valor literario el ideal de virtud de la burguesía.

Aparece así la literatura, mayoritariamente novela, de la domesticidad. Junto con las narraciones llegan los manuales de conducta y las obras pedagógicas cuyo fin es apuntalar el nuevo modelo. La novela doméstica conlleva una estética que Charnon-Deutsch (1994: 2) ha bautizado como "estética de la conformidad" (compliance), en tanto que enseña a las mujeres que deben afrontar la vida y sus problemas en soledad, sin esperar apoyo de los hombres sean estos padres, esposos o hijos ${ }^{3}$. Esta estética tiene no pocas dosis de resignación que en el caso español será cristiana y, como señalaré más adelante, es la base del discurso teórico de $\mathrm{M}^{a}$ del Pilar Sinués.

Para Alda Blanco esta respuesta conservadora de las escritoras nacidas al calor del Romanticismo es un peculiar contradiscurso, en tanto que "los perniciosos actos de escribir y leer se transforman en la piedra angular de la virtud doméstica" (2001: 86). La lectura y la escritura pierden el carácter de desorden sexual que se esconde bajo el estereotipo de Emma Bovary (2001: 56) y pasan a vincularse a la educación femenina, de manera que "la mujer doméstica [...] funciona textualmente como educadora o educanda” (2001: 86). La novela doméstica es entonces un gran programa docente destinado a conducir a las mujeres hacia el ideal burgués de esposas y madres, influyendo de modo notable en la educación femenina desde la propia trama en la que el aprendizaje de la mujer hasta llegar a ser

${ }^{3}$ Estas novelas también proponen modelos masculinos compatibles con el ideal de mujer virtuosa que, si bien no libran a los personajes femeninos de su carga personal, los acompañan de un modo en el que la esencia doméstica de la mujer no se ve violentada: "Between them there will be no secrets or mysteries; their communication will be perfect. In the presence of another who understands the abuse of gender power, docility, feminine weakness, and submission are safe virtues" (Charnon-Deutsch, 1994: 26). 
virtuosa es el eje fundamental ${ }^{4}$.

Esa educación para ser un perfecto ángel doméstico es solidaria del tiempo histórico en el que se genera: conforme la burguesía accede al poder impone un sistema de valores que la protege en lo económico, afianzando mecanismos de control sexual que, en último término, reportan beneficios patrimoniales a través de los que se tejen las redes de poder económico y político. La identificación de la esposa con este proyecto masculino se vuelve central: el discurso doméstico se convierte así en un amarre eficaz para introducir a las mujeres en un sistema de valores al servicio de los intereses económicos de la burguesía.

\section{3. $M^{a}$ del Pilar Sinués: la construcción heterodoxa de la escritora profesional}

$M^{a}$ del Pilar Sinués fue la escritora más prolífica de su tiempo y, sin embargo, apenas conservamos datos biográficos que vayan más allá de la anécdota. Nació en Zaragoza en 1835. A pesar de que no contó con un gran apoyo familiar en sus inicios como escritora, en toda su producción consagra a su madre y padre un respeto y un amor filial envueltos en una retórica de virtud y ejemplaridad moral con la que les identifica. Intuimos una total vocación literaria dado lo temprano de sus publicaciones: ella misma data una primera edición de su novela Rosa en 1851 y su primer poemario, Mis vigilias, aparece en 1854, sin llegar la autora a los veinte años.

Poco se sabe de la educación que recibió. Su formación incluyó sin duda el francés, pues se dedicó toda su vida a la traducción y siempre estuvo al tanto de la literatura del país vecino. En su producción recurre al tópico constante de aludir a su conocimiento como disperso, sencillo, ingenuo. Pero las referencias de sus textos pedagógicos y los modelos de su narrativa desmentirían esta escasez de lecturas, si bien es imposible saber

${ }^{4}$ De hecho, dos obras de Ma del Pilar Sinués (La ley de Dios y A la luz de una lámpara) fueron designadas libros de lectura en la primera enseñanza en 1860 y 1863 respectivamente. En 1865 solicita al Ministerio de Ultramar que la designación se extienda por Cuba, Puerto Rico y Filipinas, cosa que consigue. El documento puede consultarse a través del Portal de Archivos Españoles del Ministerio de Cultura, PARES (http://pares.mcu.es). a qué bibliotecas tuvo acceso y si éste tuvo lugar antes o después de su matrimonio y posterior establecimiento en Madrid.

Algunas fuentes la sitúan en el convento de Santa Rosa de Zaragoza, profesando incluso como novicia (Simón Palmer, 1991). Sin embargo, en 1856 está casada con el dramaturgo y periodista valenciano José Marco (1830-1895). La historia de su petición de mano y boda ha sido narrada por varios contemporáneos, entre ellos Julio Nombela. Una noche, en un café, se leen unos versos de la joven zaragozana y Marco, en lo que parece una broma, decide escribir un poema en el que pide su mano, ayudado por sus pares nocturnos. Nombela cuenta que lo que se inició como divertimento tomó visos de realidad porque José envió la carta a Zaragoza y recibió respuesta afirmativa. Su carteo duró un mes, se casaron por poderes y ella viajó pronto a Madrid (Nombela, 1976: 444-446). Marco trabajaba en el Ministerio de Ultramar y fundó una efímera revista llamada La España Musical y Literaria ${ }^{5}$.

La vida literaria de Marco es pronto asumida por Sinués. De hecho, ella colabora con un poema en la Corona poética dedicada al Exmo. Sr. Manuel José Quintana con motivo de su coronación, publicada en 1855 bajo la dirección del que todavía no es su esposo, puesto que firma con sus apellidos de soltera. A Quintana debemos un dato más sobre la boda, ya que corresponde a los versos de Sinués con un texto del 10 de enero de 1856 en el que le desea felicidad en sus próximos himeneos (Quintana, 1969: 393). Según Julio Nombela, Marco tenía una hija de una relación anterior, no quedando claro si era viudo. En todo caso el matrimonio se rompió, sin que se conozca el motivo, aunque muchas fuentes indirectas apuntan a que el escritor no soportó el hecho de que su esposa se convirtiera en una célebre autora, mientras que él no terminaba de descollar en el panorama

\footnotetext{
${ }^{5}$ La publicación se fundó inicialmente en 1850, pero su momento más fructífero tuvo lugar entre 1854 y 1856, cuando colaboró en ella un Gustavo Adolfo Bécquer recién llegado a Madrid. Además de en algunos números, el poeta sevillano tomó parte también en la Corona poética dedicada a Quintana que José Marco coordinó, aglutinando en ella a los jóvenes poetas románticos del momento. Intentaron obtener el patrocinio de la reina Isabel II para sostener la publicación, pero el apoyo real en forma de suscripción pareció no ser suficiente (Pageard, 1990: 29).
} 
dramático ${ }^{6}$. Sin embargo Nombela parece aludir a una infidelidad de ella que motivó una separación amistosa; no da más datos, ya que refiere el episodio como una "novela en acción" protagonizada por Sinués (1977: 446).

Julio Nombela describe a Pilar Sinués como "buena y sencilla, aunque muy romántica" (1976: 446), lo que la sitúa lejos del ideal femenino al connotar pasión, seguimiento de los instintos e irreflexión. El tópico se repite en las historias de la literatura posteriores. Lo cierto es que ella se recubrió de esa ingenuidad y sencillez supuestamente femeninas para legitimarse como autora, aunque una observación detallada de los prólogos de sus obras pedagógicas revela una autoconciencia mucho más firme y un control mayor sobre la propia obra literaria.

En El ángel del hogar, la autora narra cómo compuso Rosa: durante la noche se levantaba de forma discreta para no despertar a sus familiares y le robaba horas al sueño para escribir, atemorizada por la oscuridad y por ser sorprendida. La descripción se intensifica conforme llega la noche final de escritura en la que su madre está a punto de descubrirla. Para evitarlo, sale al balcón, con tan mala suerte que Flora Navarro cierra la ventana y deja a su hija a la intemperie, aunque no se percata de los papeles. Cuando la descubren y confiesa lo que hace por las noches, se le permite escribir en los ratos de descanso de las tareas. Sin embargo, su labor no se ve recompensada porque la ciudad de Zaragoza no la cree autora del libro, sino más bien a su padre (Sinués, 1859: 76-77). De ahí se deriva una reflexión peculiar que es el germen de los principios de ejemplaridad y realismo que Sinués va a defender en toda su obra pedagógica: "Esta ha sido la razón, lectoras mías, de proponerme afirmar con el ejemplo lo que anhelo enseñar en mis escritos, y de que estos sean, cuantas veces me sea posible, la relación fiel y verídica de hechos positivos" (1859: 78).

\footnotetext{
${ }^{6}$ El Gil Blas de 24 de marzo de 1867 se burla de una nueva publicación de Sinués en su sección "Murmullos": "La señora doña María Pilar Sinués de Marco... ha dado a luz unos Cuentos de color de cielo. / - ¿En dónde habrá visto ese color? preguntaba uno. / -En los ojos de su Pepe... contestó otro". Ángel Ma Segovia dedica unos versos a cada miembro de la pareja en su libro Melonar de Madrid de 1876. De Marco dice: "La feria de las mujeres / dio, le aplaudieron con fe; / y aun creo que presentó / en la feria a su mujer" (Segovia, 1876: 158). Los dedicados a Sinués rezan: "Más aun que por brillar / y por llegar a lucir, / escribe para olvidar / los disgustos del vivir" (Segovia, 1876: 144).
}

El prólogo de esta misma obra nos presenta su empeño de enseñar a las mujeres las ventajas de la virtud como algo sencillo y cariñoso, a imagen y semejanza de su propio razonar. Pero conforme avanza su carrera, aumenta su éxito y las reediciones se suceden (El ángel del hogar conoció siete en vida de la escritora), $\mathrm{M}^{\mathrm{a}}$ del Pilar Sinués se reviste de importancia y se considera la única persona en España que se ha preocupado verdaderamente de la educación moral de las mujeres y así lo expresa en el prólogo de Un libro para las madres (1877: 6), donde además no escatima datos, más contables que virtuosos, al respecto de las reediciones de su obra:

Puede decirse que en España soy la única persona que se ha dedicado a escribir acerca de la educación moral de la mujer; pero ¡con cuánto amor la mujer me lo ha recompensado! ¿Qué libro ha tenido una acogida tan brillante, tan entusiasta, tan admirable, tan afectuosa como mi obra Un libro para las damas? La primera edición agotada con una rapidez de que no hay un ejemplo en nuestra patria; la segunda, que casi lo está también, y las dos, vendidas en el término de algunos meses, son las mejores pruebas del amor con que aquella obra fue recibida.

En su obra La vida real: alegrías y tristezas de una familia, estudio social insiste en la idea al afirmar que "nadie en España se ha ocupado, hasta que yo lo he hecho, del bienestar, de la dicha moral de la mujer, nadie le ha dicho - Yo te alumbraré en tu camino para que no caigas" (1884: 6). Vemos que del consejo de amiga realizado con el afán de ser útil pero sin darse excesiva importancia, pasa a afirmarse como la única escritora de su tipo en España. Pero va más allá porque establece sus modelos literarios e ideológicos en Francia, haciendo una sutil maniobra que la compara con las grandes escritoras francesas contemporáneas, cuyo prestigio y aceptación en el país vecino eran mayores de los que gozaban las autoras españolas.

Su dominio de la publicidad editorial de la época no se corresponde tampoco con el de una sencilla joven que escribe por puro don o instinto. Recurre en varias de sus obras a la táctica del manuscrito encontrado o enviado a su persona en tanto que lectora competente que entenderá las penas que en el texto se narran. Los prólogos se ven salpicados así de ficciones en las que entra en juego su rol de escritora, y la recepción si- 
multánea de bastante feedback por parte de su público. Tal es el caso de la primera pieza que contiene la ya citada Un libro para las madres, en la que una mujer le hace llegar la trágica historia de su vida porque la considera la única confidente posible en el momento final de su existencia. Estas son las razones:

el mundo ha concluido para mí.

En él diviso aún una figura circundada de paz, rodeada de una blanca luz... la de V., la de V., que se ocupa sin cesar de ofrecer a las jóvenes los dulces frutos de su pluma; las sanas máximas de la virtud. Hija mía, - porque por mi edad bien le puedo dar ese dulce nombre- hija mía, yo la confío lo que escribí para mi hija; yo la confío mis sueños y las realidades que al fin de ellos he hallado; délos V. a la luz, y la ahorrarán quizá algunas horas de trabajo, si los juzga dignos de figurar entre las bellas y aromadas flores de su moral y recreativa Biblioteca.

Todas las obras de V. las tengo; de ésta, tal vez llegará un día en que yo misma vaya a pedirla un ejemplar; pero eso será cuando esta dolorosa llaga de mi alma haya dejado de sangrar; entonces sabrá quién es una de las más desgraciadas mujeres del mundo, y también una de sus más fervorosas y apasionadas admiradoras (1877: 12-13)

Esta inclusión de su faceta de escritora como personaje en una de sus obras, o el constante elogio de su propia labor, es una de las brechas a través de las cuales acercarnos a la mujer real que se escondía bajo la imagen de la humilde y modesta escritora del hogar. En la crítica a Rosario de Acuña ya citada, Pilar Sinués nos dice mucho sobre su propia percepción como mujer y como escritora. Afirmando que se puede ser librepensadora pero no hablar o escribir con libertad, la autora zaragozana pone sobre la mesa el juego de máscaras que una escritora como ella tuvo que desarrollar para mantener el éxito público y proseguir su carrera literaria. La performance empieza antes de los manuales de conducta que tipifican roles y demarcan prohibiciones para las mujeres. La escritora tiene también que actuar ${ }^{7}$, que ser en apariencia uno de sus personajes, para poder llegar a la imprenta, dejando a buen

${ }^{7}$ Volveremos sobre este asunto en el apartado final. Baste por ahora señalar que la teoría de la performatividad de género desarrollada por Judith Butler (1990) se expresa aquí no sólo en la textualidad, sino en la construcción identitaria de la escritora: hay un efecto espejo entre lo que pretende Sinués y cómo debe explicarse a sí misma. recaudo las facetas más problemáticas de la identidad.

Pilar Sinués parece ceñirse a los preceptos neocatólicos según los cuales las escritoras deben tomar la pluma para hablar de la virtud, de la vida doméstica, de la religión o del amor casto (maternal o filial). Cuando consigna la escritura como una dedicación posible para las mujeres lo hace siempre como último recurso, preservando esa idea de que en último término ha de ser un impulso del corazón pero no un ejercicio varonil. De hecho, algunas de sus heroínas escriben para sus hijas pero no tienen intención alguna de dar los textos a la imprenta, insistiendo en la función educadora de la madre y de la propia escritura doméstica (Blanco, 2001). Soslaya bien su carácter excepcional al presentarse como amiga y consejera: primero con modestia, después, como hemos visto, afirmando claramente que ella es única en su condición.

Sobre lo que deben escribir las mujeres, Sinués afirma lo siguiente en Verdades dulces y amargas (1882: 295):

No aconsejaré a ninguna mujer que, ni aun dentro de la esfera del arte, consagre su talento a obras viriles: es decir que me parece tan impropio de una mujer el pintar cuadros de historia, como el escribir libros donde las pasiones fuertes traigan como consecuencia la inmoralidad y los crímenes: bueno es que pinte el mal, pues sin conocerlo nadie puede evitarlo, y la ignorancia no es la virtud: pero con cierto pudor, con la delicadeza que debe ser inherente a la condición femenina [...]

Las novelas de brocha gorda, así como los grandes cuadros de batallas, no son propios de la dulce y suave condición femenina.

Constantemente, además, alude a que su pretensión al escribir su propia obra es ayudar a las demás mujeres, no faltando ni a la verdad ni a la virtud, teniendo por intención dar consuelo. Sin embargo, en sus publicaciones plenamente narrativas, Sinués se ciñe a otra opinión: "El escritor no puede estacionarse: debe marchar con su época" (1882: 7). Así, en 1861 publica Fausta Sorel, una novela que, tal y como ha señalado Sánchez Llama (1999: 275), sorprende a la crítica y en cuyo prólogo se alude a Balzac como referente. Para el investigador esta obra es la que quiebra un tanto el equilibrio entre discurso isabelino y contemporaneidad en la narrativa de Sinués, si bien dentro de los términos estrechos de la ideología conser- 
vadora de la autora. Esta ruptura es, siempre según Sánchez Llama, la que explicaría por qué Sinués tuvo éxito tanto en el reinado isabelino como en la Restauración, al contrario que otras de sus contemporáneas, quienes no adaptaron su estilo y temas a las nuevas preocupaciones que corrientes como el Realismo y el Naturalismo introdujeron en la literatura.

Cuando Sinués habla de la composición de la novela, dice que sin dejar de ser escritora del hogar pretende "empuñar el fuerte cincel que se necesita para modelar la estatua del vicio que presento bajo el aciago nombre de Fausta" (1861:2). El personaje es descrito en términos que anticipan las temibles mujeres fatales del fin de siglo, a pesar de que Sinués vaya a redimirla a través de la muerte en el final del texto. De Fausta dice que es: "una diosa, una reina del infierno, una criatura más inmensa, más grandiosa, más imponente que cuanto encierra el mundo... [...] un ser sobrenatural y aterrador: grande así en sus crímenes como en las apariencias de su virtud" (1861: 18).

Es por ello claro que las opiniones sobre la escritura vertidas en la producción pedagógica distan mucho de ser las actitudes tomadas por la autora en su novelística. Pareciera como si, alcanzada la legitimidad como escritora doméstica y virtuosa, la zaragozana pudiera permitirse revelar más de sus horizontes literarios pero haciéndolo en su obra puramente narrativa. Tratándose de una escritora con una producción tan amplia, es especialmente interesante estudiar estas estrategias de publicidad editorial relacionadas, por un lado, con el tipo de textos en los que las inserta y, por otro, con la aplicación o no de sus propios principios legitimadores en su literatura. La frontera entre vida y discurso se traslada a los textos, permitiendo asomarnos frontalmente a la paradoja de la escritura femenina en el siglo XIX.

\section{Educando al "Ángel del Hogar": un modelo de conducta para las españolas de clase media}

A la hora de definir qué textos de $\mathrm{M}^{\mathrm{a}}$ del Pilar Sinués pueden considerarse pedagógicos, he partido del inventario realizado por Simón Palmer (1991) en el que la investigadora recoge cerca del centenar de volúmenes. sta está compuesta por El ángel del hogar. Obra moral y recreativa dedi cada a la mujer (1859), Un libro para las damas. Estudios acerca de la educación de la mujer (1876²), Un libro para las madres (1877), Hija, esposa y madre. Cartas dedicadas a la mujer acerca de sus deberes para con la familia y la sociedad $\left(1877^{2}\right)$, La mujer en nuestros días (Obra dedicada a las madres y a las hijas de familia) (1878), Un libro para las jóvenes. Estudio social (1879), La dama elegante. Manual práctico y completísimo del buen tono y del buen orden doméstico (1880), Verdades dulces y amargas. Páginas para la mujer (1882) y La vida real: alegrías y tristezas de una familia, estudio social (1884).

Bajo estos títulos se esconden diferentes tipos de textos: artículos, digresiones de corte ensayístico, diarios íntimos, memorias, novelas breves y novelas en cartas entre dos o más personajes. En algunos casos una misma obra se escribe recurriendo a varias de estas fórmulas. En lo tocante a los artículos, he podido constatar que, por ejemplo, los que componen Un libro para las damas, cuya segunda edición data de 1876, aparecerán publicados en las páginas de El Imparcial varios años después, aunque proceden en algunos casos de revistas previas como El ángel del hogar, dirigida por la autora entre 1864 y 1869, u otras destinadas al público femenino.

El libro El ángel del hogar aparece en 1859, pero está compuesto por textos publicados en la revista La Moda de Cádiz a lo largo del año anterior. Su carácter es misceláneo porque sobre una base de texto ensayístico estructurado en ocasiones como artículos de periódico entrelazados, la autora intercalada varias historias de ficción que le sirven para ilustrar los principios que está proponiendo. La crítica ha querido ver en el conjunto una obra compleja en cuanto a estructura y ligazón del trasfondo ideológico (Blanco, 2001), pero lo cierto es que más parece que la autora quería deshacerse de algunos proyectos inacabados que inserta al hilo de su ar-

${ }^{8}$ He prescindido conscientemente de sus colecciones de cuentos o fábulas religiosas, pues aunque Sinués emplea la ficción en algunas de las obras que voy a analizar, la recurrencia de temas y situaciones me permite centrarme en otras tipologías discursivas. No considero que esta selección de nueve textos esté cerrada, si bien me parece que son los más representativos y que, cronológicamente, permiten una visión coherente de la evolución ideológica de la escritora.
Las obras que he seleccionado como claramente pedagógicas son nueve ${ }^{8}$ 
gumentario principal sin que sea evidente su pertinencia para el conjunto del libro.

Un libro para las damas $\left(1876^{2}\right)$ está compuesto, como he dicho, de artículos periodísticos, cuyos breves títulos nos revelan la vasta temática de la obra: "La poesía del hogar doméstico", "Los celos", "La belleza y la gracia", "La verdadera cristiana", "Las armas de la mujer", "El trabajo", "El verdadero talento", "La modestia”... También se compone de este tipo de artículos la segunda parte de Un libro para las madres (1877), siendo la primera el manuscrito encontrado. El enlace entre ambas lo da la propia escritora cuando dice que los artículos son "como la teoría general de los deberes de madres” (Sinués, 1877: 5). En Hija, esposa y madre $\left(1877^{2}\right)$ recurrirá a la estrategia de las cartas cruzadas entre los muchos personajes de la obra. La mujer en nuestros días (1878) también es una novela en cartas sólo que, en este caso, entre dos interlocutoras.

Un libro para las jóvenes (1879) consta de dos textos que no tienen una relación explícita más allá de la intención pedagógica general. El primero se titula Correspondencia entre dos hermanas y el segundo es el Diario de una joven pobre. La dama elegante (1880) es sin embargo un manual para convertirse en perfecta ama de casa. Además de los artículos del tipo moral ya citados en otras obras, incorpora recomendaciones sobre la elección del barrio, de la casa, de los muebles; sobre la disposición de las habitaciones por clase y sexo en el hogar; sobre la forma de relacionarse con el servicio, etc. Añade además consejos de limpieza de diferentes materiales, remedios populares para enfermedades infantiles y recetas de cocina.

Verdades dulces y amargas (1882) vuelve a ser un libro de artículos aparecidos previamente en El Imparcial y que tratan los temas ya vistos. En este caso podemos leer también reseñas de obras literarias o incluso textos más preocupados de temas contemporáneos a través de la descripción de los tipos de mujer de otras naciones como Reino Unido, Francia o Alemania en comparación con España. Finalmente, La vida real (1884) es una novela construida a través de las cartas que se cruzan sus protagonistas. Se trata de un compendio voluminoso en el que Sinués lleva al extremo su estilo tanto en la teoría moral como en la exageración de recursos melodramáticos. 
señala que "involucran de un modo más patente a la amiga al hablar de la intimidad y, por estar escritas con el ánimo de resolver los problemas personales a través del carteo con otras mujeres, suelen tejer una red de apoyo mutuo" (2001: 193), algo que también sucede en el uso que les da Sinués.

Esta novela en cartas española no es ajena en fechas al éxito de este género en Europa y de ahí deriva la otra parte de los modelos y fuentes de la autora zaragozana. Muy en concreto, su mirada se posará sobre importantes escritoras francesas del período de entresiglos, entre las que destacan Madame de Genlis (1746-1830), la Condesa de Bassanville (1806-1884), Madame Cottin (1770-1807) y Madame de Stäel (1766-1817); también una escritora temprana como Madame de Sevigné (1626-1696). Ma del Pilar Sinués conoce la obra de todas estas autoras y emplea en su propia producción aquellos preceptos o estrategias discursivas que le son útiles, rechazando lo que no le conviene en lo ideológico.

\subsection{La "estética de la resignación" como marco ideológico}

$M^{a}$ del Pilar Sinués se cuenta, como he señalado, entre quienes se preocupan por la educación moral de las mujeres españolas desde una perspectiva católica y conservadora. Me interesa ahora estudiar su ideología de género en relación con los grandes temas abordados en sus obras pedagógicas, así como los vínculos de la escritora zaragozana con el feminismo contemporáneo en España. La variabilidad de asuntos y la cantidad de obras escogidas me han llevado a seleccionar cuatro líneas principales en la reflexión sobre sus propuestas: la educación, el trabajo, la familia y los rasgos morales (la esencia) del modelo de mujer que la autora defiende como típicamente español y adecuado a la religión e historia del país. Todos estos factores se aglutinan en torno a la "estética de la conformidad" propuesta por Lou Charnon-Deutsch como base explicativa de la ideología de la ficción doméstica. Prefiero, sin embargo, hablar de una estética de la resignación, ya que encaja mejor con los mecanismos católicos de subordinación de las mujeres en la vida terrena, a la espera de la felicidad en la vida eterna, por los que se caracteriza la moral tradicional española.

$M^{a}$ del Pilar Sinués considera importante que las mujeres españolas entiendan que la virtud no es algo áspero y sacrificado, sino que tradicionalmente se la ha pintado de forma poco favorable para su ejercicio. Ella llega entonces dispuesta a hacer valer "la poesía del hogar doméstico" (Sinués, 1876: 11) y a demostrar que es fácil ser virtuosa cumpliendo unos sencillos preceptos que se resumen en la idea general de bondad. Por ello, presenta las tareas y obligaciones como algo grato a la condición naturalmente maternal de las mujeres, de forma que lo más sencillo para una vida apacible es seguir su propuesta.

Junto a la voluntad de presentar la cara amable de la virtud, Sinués plantea a las claras que la vida de las mujeres no está llamada por la senda de la felicidad, sino que su misión es ardua, la sociedad no las entiende y el sufrimiento está garantizado. El mecanismo de la resignación funciona cuando consigue hacer ver la superioridad del destino femenino sobre la tierra, dejando la vida feliz para el reino de Dios y proponiendo, de forma indirecta, que la actitud masculina será siempre inferior al imperativo moral-maternal que rige la vida de las mujeres.

Un análisis detallado de esta resignación como única salida a los desajustes familiares de los personajes permite acceder a una pequeña transgresión en este modelo tan sólidamente conservador. Ma del Pilar Sinués se revela pragmática. No hay en su obra pedagógica príncipes azules que vengan a rescatar a los ángeles domésticos y a proporcionarles el tan ansiado final feliz, aunque en sus textos triunfe la familia y a simple vista parezca que las jóvenes obtienen la felicidad en su tarea de esposas y viven en armonía con unos maridos cuya autoridad no ha sido en apariencia cuestionada.

En realidad, el final adecuado no va a llegar por la acción del hombre, como se esperaría en un marco en el que se admite su superioridad, sino por la actitud de la protagonista femenina. Ante los maridos desatentos y adúlteros, a las jóvenes les queda mantener una dignidad que no se confunda con la altivez, mientras siguen adelante con sus obligaciones sin emitir una queja. Cuando esto se produce, las protagonistas entran en un camino próximo a la mística, ya que el sufrimiento que padecen pero no muestran las consume físicamente y las acerca a la muerte. Sin embargo, esa actitud, ese sublimarse en lo angelical, genera como consecuencia la 
conversión de todas las personas de su entorno, empezando por sus esposos. Ellos, fulminados al caer en la cuenta de que tienen ante sí poco menos que a una mártir cristiana, se arrepienten de sus errores y cambian por completo su conducta, convirtiéndose en compañeros ideales de la protagonista. Objetivamente, esa dignidad femenina es arma de poco fuste, ya que no cuestiona la subordinación y la sumisión, pero ofrece una variante que no encaja del todo en el teóricamente inquebrantable conservadurismo de la autora: las mujeres salen adelante solas 9 .

Este criterio independiente de los personajes femeninos no pasó del todo inadvertido a la crítica. Julio Cejador y Frauca dice de Sinués que es:

[...] nada notable ni por los caracteres ni por la pintura de costumbres, bastante sensiblera y empalagosa en sentimientos y afectos; $y$, aunque pretendiendo ser moralizadora, quédase con ser docente escritora para señoras y niñas, pero de una moral algo peligrosa, cual es la que enseña a seguir las propias inclinaciones (1915: 141).

Los manuales posteriores repiten esa advertencia final: la autora invita a seguir las propias inclinaciones y, aunque una lectura de su obra muestra que siempre lo hace dentro de parámetros católicos, está defendiendo al fin y al cabo una cierta autonomía moral para las mujeres. En sus ficciones, esta convicción angelical les permite alcanzar el bienestar material, dándose así esos finales si no felices, al menos agradables en los que la prosperidad material, la falta de violencia física y el amor cordial entre los miembros de la familia se consideran el escenario de éxito al que debe aspirar en vida cualquier mujer.

\footnotetext{
${ }^{9}$ El caso más claro en las obras analizadas es el de Mélida de Campoverde, una de las protagonistas de Hija, esposa y madre. A pesar de su condición noble, decide casarse con Juan Bautista, procedente de una familia de labriegos acomodados. Ella le convierte en un hombre de provecho al apoyarle en su educación y, cuando es más inteligente que ella, empieza a despreciarla hasta llegar al punto de tener una aventura. El abandono de la amante le sume en la más absoluta demencia pero Mélida insiste en cuidar de él y en mantenerse en el hogar con sus hijos, a pesar de que todo su entorno vería adecuado que internase al esposo. Finalmente, éste sale de su locura y reconoce la labor de la esposa que, en todo el proceso, ha sufrido físicamente las consecuencias de su dolor espiritual. Recuperado Bautista, todo vuelve a la normalidad.
}

\subsection{Las españolas según $M^{a}$ del Pilar Sinués: esencia, familia, educación y trabajo}

El modelo femenino del "Ángel del Hogar" comparte unos rasgos comunes relacionados con la maternidad, la subordinación al varón, la religiosidad, la asexualidad y la bondad. A la vez que sostiene este modelo en sus artículos y a través de sus personajes, la autora incorpora una defensa de su labor y de la compatibilidad de la literatura con el hogar. Emplea para ello tres argumentos: señala ejemplos de escritoras ilustres que han sido también buenas amas de su casa y de su fortuna (junto a Madame de Stäel citará paradójicamente a George Sand); precisa que la literatura debe dejarse para después de cumplir con las obligaciones familiares y marca una vía de temas y géneros muy clara para la escritora, que es la que ella misma encarna en su producción pedagógica. Así, reiterará en todas sus obras moralizantes que "si hay alguna cosa que disculpe en la mujer el atrevimiento de escribir para el público, es sin duda la buena intención con que debe hacerlo" (1876: 253). Esa "buena intención" se va a concretar en escribir para su descendencia o para sus iguales, libros en los que pinte la virtud, la bondad y la belleza, vetando así obras que ahonden en temas y caracteres que Sinués considera adecuados solo para la pluma de los varones.

Del mismo modo que defiende una literatura femenina por oposición a la masculina general, Sinués va a plantear que el modelo de mujer que ella busca en las españolas no tiene nada que ver con el que se da en Europa. En este punto encontraremos una opinión principal y una salvedad recurrente que aparece en su obra en torno a 1870 . La postura fundamental es que a la mujer española le basta con ser buena esposa y madre, no necesita acceder a los caminos de la ciencia, el comercio y la política. La salvedad es plantear los escenarios de otros países como veladamente adelantados al español, de forma que hasta que estemos en la situación de aquellos, nos conviene más una propuesta como la suya: educar a las hijas para que en caso necesario puedan ganarse la vida, librarlas del riesgo de ser unas marisabidillas que se queden solas y, en general, combatir en lo posible los problemas que el progreso entraña para unas mujeres en situación jurídica de franca desigualdad. Hace esto sin condenar ideológicamente la realidad de esos otros países, aludiendo sin más a la diferencia pero poniendo en valor que en ellos se ha visto la importancia de la edu- 
cación para ganarse dignamente la vida, en una Europa en la que vivir del trabajo personal se vuelve mucho más importante que la fortuna heredada, tanto para los varones como para las mujeres:

Ya el camino de la ciencia se va abriendo para el sexo débil en algunas naciones vecinas y amigas de la nuestra: ya las señoras están asistidas en sus dolencias por otras señoras, y tras el mostrador de las oficinas de farmacia se sientan lindas jóvenes, cuya vista calma algún tanto la pena del que va en busca de un medicamento para una persona a quien ama y que padece [...]. Pero en España aún no estamos en ese caso: la ciencia no ha abierto todavía sus puertas a la mujer, y aún la industria cuenta poco con ella, y rara vez llega en su ayuda.

Y sin embargo, la que te escribe, Julia, piensa que se pueden abrir para la mujer en nuestro país, sino anchos caminos, a lo menos alguna senda por donde camine con tranquilidad ayudada del trabajo; por una senda donde no halle la opulencia, pero sí un bienestar relativo, una decente medianía, o a lo menos, una honrada pobreza (1878: 208-209).

Con todo, el destino preferible para las mujeres sigue cifrándose en el matrimonio y en la maternidad. Así, en toda la producción pedagógica de Sinués, la familia burguesa es la verdadera protagonista pues es el escenario de sus consejos y reflexiones. La vida de las mujeres tiene un sentido y unas funciones según la etapa en la que se encuentren: hija, esposa o madre. La maternidad es función principal, ya que "la existencia de la mujer empieza cuando va a darla a otro ser" (1859: 125) e incluso puede ejercerse sin descendencia a la manera de una "maternidad moral" (1876: 335) y a través de la caridad.

Durante el tiempo en que la joven vive en la casa de su padre tiene lugar todo el proceso de educación y entrenamiento para la conversión en ángel doméstico. Cuando llega la adolescencia, sus protagonistas requieren siempre la concurrencia de una amiga con la que compartir sus desvelos y de la que obtener consejo. Encontrar el novio adecuado y convertirlo en marido ocupa muchas páginas de los textos de Sinués. Para ella lo conveniente es que el primer amor pase a ser el esposo, pero lo cierto es que va a consignar durante décadas que "el primer amor de la mujer es casi siempre vendido por el hombre" (1859: 210). Las prendas que adornan al marido ideal construyen un arquetipo de joven de la clase media que por su esfuerzo educativo adquirirá un buen trabajo y mantendrá con bondad, pero férreamente, la autoridad sobre su familia. Desaconseja escoger por esposo a un hombre descontento con el mundo en el que vive o convencido de su propia genialidad, recomendando siempre a personas en las que el justo medio ${ }^{10}$ sea su guía vital (1877: 298). El marido debe ser el jefe de la familia pero también debe educar a la esposa, moldearla hasta convertirla en el perfecto ángel. En 1859, con su boda reciente, para dar peso a este argumento habla de su propia experiencia:

[...] de mí sé decir, que mi carácter era tan indeciso, cuando me reuní con mi esposo, que no merecía siquiera el nombre de tal. La acertada dirección del hombre a quien uní mi destino, el conocimiento de mis deberes y el amor que le profeso, han cambiado totalmente mis ideas y han obrado en mí una reacción completa (213).

Para la buena armonía del matrimonio, Pilar Sinués ofrece unos principios básicos en su obra de 1859 que serán la base de la conducta femenina a lo largo del resto de su producción pedagógica:

Conquistad el corazón de vuestros esposos, no con la virtud ceñuda, sino con la virtud dulce y graciosa, con la bondad, con la coquetería.

Hacedles agradable su casa y amable vuestro trato.

Sed sus amigas al mismo tiempo que sus amantes.

Partid sus alegrías.

Consolad sus tristezas.

Endulzad sus dolores.

Cuidad sus enfermedades.

Esmeraos en su elegancia.

Procurad que nada les falte a su tiempo.

Velad por los intereses de la casa, que son los vuestros también.

Haceos, en fin, necesarias a su dicha y dejadlos libres, completamente libres.

${ }^{10}$ Esta recomendación de justo medio esconde lo que Aranguren señala como la voluntad de orden del moderantismo español. No hay un sentido ético de la templanza sino un deseo de evitar el escándalo o el caos (tanto de índole política como por supuesto sexual) (Aranguren, 1982: 77-80) 
No les preguntéis a dónde han ido, que ellos mismos os lo dirán espontáneamente.

No les preguntéis por el dinero que han gastado, que es rebajarlos a sus propios ojos, y las heridas del orgullo son las que menos han de perdonaros. El hombre es el jefe natural de la familia y el dueño de su casa: para impedir sus extravíos, no tenías más medio lícito que imperar en su corazón (1859: 509-510).

La autora compendia en el fragmento citado la base de su ideología resignada: las mujeres deben hacerse imprescindibles a sus maridos a través de la bondad, la sumisión y la alegría, en absoluto haciendo gala de una virtud ceñuda. Es curioso que Sinués ponga en valor una manera de vivir el matrimonio en la que la mujer puede convertirse en compañera del varón siempre que lo envuelva en un lazo de afecto y dependencia que haga que, de forma natural, éste la considere imprescindible en su vida y le haga partícipe de los intereses de la casa de ambos. De ahí la insistencia en el aspecto físico del matrimonio, en velar por la casa como forma propia a través de la cual la mujer defiende la hacienda común... en definitiva a través de una conducta sumisa pero alegre y repleta de amor, las mujeres pueden llegar al ideal de matrimonio burgués que la autora defiende, en el que impera una complementariedad regida por el cabeza de familia.

$\mathrm{M}^{\mathrm{a}}$ del Pilar Sinués condena la ignorancia de la mujer que genera matrimonios excesivamente desiguales en lo intelectual y conduce al fracaso. Piensa que la esposa debe tener una instrucción regular que le permita conversar con su marido y participar de la vida de él a través del diálogo, única manera de interferir en sus decisiones. Plantea también que la mujer no ha de descuidar su aspecto físico una vez casada, aunque sea una buena madre y mantenga el hogar en perfecto estado: debe mostrarse siempre hermosa y agradable. Bajo esta precursora de la mística de la feminidad se esconde el principio de que los hombres son niños grandes y a las mujeres que desean ser felices en el matrimonio les está reservado adularlos y emplear la coquetería para rendirles por su propia vanidad.

La situación más difícil que afronta la esposa en el seno de la familia es el adulterio. En toda su producción pedagógica, Sinués plantea diferentes escenarios y modos de actuar por parte de sus personajes. El ideal es el ya citado al hablar de la dignidad resignada como arma posible: seguir actuando como la perfecta esposa y madre, no llorar, no hablar del hecho y esperar a que el marido se dé cuenta de todo y recapacite. Pilar Sinués muestra un rechazo total por las separaciones, considerándolas la solución peor para la honra de la propia mujer, que se verá sometida a un escarnio social implacable ${ }^{11}$.

El papel de la mujer como madre está asociado en todas sus obras al amor. También a la responsabilidad sobre la educación de la descendencia y sobre su primera instrucción, que será casi la única en el caso de las niñas, ya que su entrada en el sistema escolar no está prevista. El referente moral de la madre es la virgen católica, a la que Sinués invoca constantemente y pone como ejemplo. Por ello, el papel de las madres es introducir a sus criaturas en la fe y en la oración, pero también en los valores de esfuerzo, trabajo y dignidad personal de la clase media.

Esta vida como hija, esposa y madre tiene por escenario la casa burguesa y las costumbres de esa clase. Aunque Sinués insiste en que sus ideas deben llegar a los hogares más humildes recurriendo al tópico de que la dignidad del obrero está en su limpieza, lo cierto es que sus consejos sobre el mueblaje, la distribución de habitaciones, el trato con el servicio y la tipología de las reuniones sociales están pensadas para una familia acomodada en la que el hombre tiene una posición destacada en la sociedad y la mujer vive en simbiosis perfecta con la casa para representarle en las ocasiones en que los salones se abren a la vista del mundo.

$\mathrm{M}^{\text {a }}$ del Pilar Sinués no deja un solo aspecto a la imaginación. Incluso habla de las habitaciones para niñas y niños, algo no común en los tratados sobre el tema que se escriben contemporáneamente en Francia (Perrot, 1992: 37), señalando la importancia de que duerman en habitaciones separadas. Para las niñas diseñará cuartos inspirados en el que parece el de

${ }^{11}$ La autora habla de la situación legal del matrimonio y la posibilidad de regular el divorcio en una sola ocasión en su obra pedagógica. Lo hace por boca de Diego, uno de los personajes de La vida real (1884). Este hombre se siente atrapado en un matrimonio infeliz que desearía romper y es presentado como alguien inconstante y pasional, no excesivamente inteligente. Por lo tanto, al situar la defensa del divorcio en un personaje que no cuenta con las simpatías de la escritora, insiste en juzgarlo negativamente. 
su infancia por cómo lo rememora en toda su obra: una cama, un crucifijo, una jaula con un pajarillo, alguna planta, una pequeña balda en la que haya unos pocos libros muy bien escogidos (recomendando sin rubor los suyos) y un espacio de trabajo destinado especialmente a la costura.

La educación de las mujeres es el tercer pilar en el que se asienta el discurso pedagógico de $\mathrm{M}^{\mathrm{a}}$ del Pilar Sinués. En sus textos, como en la época, es un concepto amplio que engloba más ideas que la mera instrucción (adquisición de unos determinados conocimientos) y que tiene que ver también con la formación moral. En su reflexión se mezclan, entonces, la capacidad intelectual de las mujeres, el papel de las madres en la educación de la descendencia, la formación adecuada al sexo femenino y los aspectos morales que convierten a las jóvenes en transmisoras de los valores tradicionales.

Sinués considera que la capacidad intelectual de las mujeres es diferente e inferior a la de los hombres en aspectos relacionados con lo que ella llama ciencia y erudición. Sin embargo, censura que muchos varones no quieren elevar el nivel intelectual de las mujeres porque eso es causa de graves problemas en el seno del matrimonio y en la sociedad. Dado que no contempla una igualdad intelectual o de misiones en la vida, su petición de una instrucción básica para las mujeres se asienta en un curiosa equivalencia: "Es absolutamente necesario que se eduque a la mujer en relación al fin social que está llamada a cumplir; es necesario que el sentimiento inteligente de la mujer alcance, aunque por otro camino, los mismos grados de elevación que la cultura intelectual del hombre" (1876: 6).

En el mundo polarizado erigido en su obra pedagógica, el sentimiento inteligente femenino ha de tener el mismo valor social que la cultura intelectual del hombre, produciendo una falsa sensación de equidad en la importancia de las responsabilidades asignadas socialmente a cada sexo. Sólo desde este marco, $M^{a}$ del Pilar Sinués puede quejarse de la situación en la que se encuentran las mujeres y reclamar mejoras que eleven su instrucción sin contravenir el principio básico de la inferior capacidad intelectual femenina del que hace partir su análisis, insertándolo en el discurso dominante. De esta manera, lo que parece una demanda transgresora de educación femenina se concreta en una petición que encaja sin fisuras en el mundo burgués de las esferas separadas, ya que toda reclamación educativa se va a relacionar con la condición de futura madre o compañera de un varón al que, por lo menos, tiene que ser capaz de entender.

A lo largo de su producción, insiste en que su programa educativo pasa sobre todo por aprender a ser buenas hijas, esposas y madres. En ello tendrá gran importancia la costura y el cuidado de la casa, habilidades ambas que pueden adquirirse desde la infancia. Las mujeres deben tomar “afición y apego a las labores de adorno" (1876: 288). Sinués recomienda la lectura, pero siempre que no interfiera con el trabajo y que el contenido sea moralmente intachable; para ello no duda en promocionar sus propias obras. Educar a las mujeres es hacerles entender que sus obligaciones son diferentes a las de los hombres: a ellos les compete la lucha exterior, a ellas, garantizar el sosiego y la paz de la familia (1876: 6). En cuanto a la pura instrucción, esta tendrá siempre un claro fin utilitario:

Para conseguir que [la joven] sea útil es preciso instruirla con perfección en uno de los ramos del saber humano, y muy preferentemente en lo que se relacione con las manifestaciones del arte, que es lo que está más acorde con la imaginación apasionada de la mujer española.

Se debe enseñar a las jóvenes alguna cosa, con tanta solidez y perfección, que puedan ellas enseñarlas a su vez a las demás; porque la música, la pintura, los idiomas, son manifestaciones de la instrucción de la mujer, que puede transmitir con utilidad propia y ajena a otras mujeres, y a los niños de ambos sexos (1878: 210).

El supuesto apasionamiento de las españolas debe conducirse hacia la adquisición de un saber relacionado con las artes que, llegado el momento, puedan enseñar dentro de los límites del decoro, empezando por su propia descendencia. La madre educadora que persigue formar Sinués a través de su obra tiene por rasgos dominantes la bondad y el sentimiento cristiano, únicas guías necesarias de su acción. Debe inculcar en sus hijas los valores morales descritos anteriormente y corregir aquellas desviaciones que aparten a la joven del camino deseado, desviaciones de las que si no, será responsable. Además, es importante que, dada la inestabilidad económica de su mundo contemporáneo, eduque a niños y niñas en valores de humildad y trabajo, evitando así que caigan en la tentación del peli- 
grosísimo lujo que no se cansará de condenar y que asocia a la aristocracia degenerada (Aldaraca, 1992).

Sinués tiene claro que la educación de la niña es sencilla porque si en su hogar habita una madre tan modélica como las que pueblan sus textos pedagógicos, sólo será necesaria la imitación para reproducir el esquema. Por otro lado, hace especial hincapié en que las madres no eduquen a sus hijas para otra cosa que no sea lo socialmente esperable: "Ninguna madre que anhela la felicidad de su hija, y creo que lo serán todas, debe educarla para que sea un espíritu fuerte; cuanto más mujer y más delicada, será más interesante, y alcanzará más amor y más protección, que es su precisa consecuencia" (1882: 295). Como repite a lo largo de toda su obra, la única manera en que una mujer inteligente puede hacerse perdonar en sociedad esa condición monstruosa es mostrándose humilde, paciente y buena con todas las personas de su entorno. El resumen de su propuesta pedagógica, amparada en los conceptos de bondad y belleza a los que debe inclinarse el alma femenina, se concreta en estas pocas líneas:

Hacer a la mujer buena, e instruirla, para que en caso de necesidad se baste a sí misma, es una grande obra que está por comenzar; hacia ella llamamos la atención de todos los espíritus generosos; y no es que deseemos la extinción del hogar, puerto de paz, donde el hombre descansa de sus fatigas y sinsabores; no, lo que deseamos es la ilustración del hogar, y que éste se haga lo más agradable posible (1877: 400-401).

La necesidad acecha de continuo el mundo de $\mathrm{M}^{\mathrm{a}}$ del Pilar Sinués y su reflexión parte de la situación económica contemporánea pero también de su propia experiencia como mujer que se sostiene a sí misma con su trabajo de escritora. Para prevenir la contingencia de un futuro sin padres o sin esposo que puedan mantener a la joven, introduce en su obra la demanda de esa instrucción útil que permite a las mujeres desempeñar ciertas profesiones sin poner en peligro su virtud.

Pero para $\mathrm{M}^{\mathrm{a}}$ del Pilar Sinués el trabajo ha de ser una constante en la vida de las mujeres, produciéndose entre las paredes del hogar doméstico. El gran enemigo de la moral tradicional es el ocio mal empleado, pues las jóvenes sin ocupación constante corren el riesgo de caer en las trampas de su propia imaginación. Las novelas inapropiadas leídas en esos ratos desocupados abonan el terreno fértil para el caos que se da en las almas femeninas, si no están domesticadas por el trabajo constante. Para ello, es muy importante programar las actividades diarias desde primerísima hora y mantener unas rutinas estables durante toda la vida que no dejen espacio a la ensoñación:

Las horas son como cajas practicadas en el día para recibir nuestras acciones, y ¡cuántas se pueden colocar en cada una de ellas, si no se deja pasar ninguna sin llenarla! Sí, la vida es un tejido de deberes que cumplir, encadenados los unos a los otros; no se puede romper un eslabón de esta cadena sin ocasionar un desorden más o menos irreparable (1880: 58).

Es importante que estas tareas sean eficaces pero se hurten a la vista de los varones (padres, hijos o esposos), pues "la economía doméstica es una máquina que el hombre gusta de ver funcionar, pero cuyas ruedas, cordaje y mecanismo interior, jamás debe ver, cuyo áspero chirrido jamás debe oír" (1877: 301). Bajo el membrete de economía doméstica, la escritora dota de condición científica a las labores del ama de casa y da prestigio a su propia obra pedagógica, cuyo fin último es ayudar a que las mujeres tomen conciencia de su trabajo natural y lo cumplan a la perfección.

Las obras de $\mathrm{M}^{\mathrm{a}}$ del Pilar Sinués están llenas, sin embargo, de muchachas desamparadas por las quiebras bursátiles de sus progenitores, a las que se les hace imprescindible trabajar para mantener lo que queda de sus familias (generalmente a sí mismas y a sus madres). Estas jóvenes sufrirán diversas penalidades y acabarán recompensadas con un ajuste en su posición -por el matrimonio- que no tiene por qué significar el abandono del trabajo, pero que las premia con la función de madres. Los oficios que desempeñan se realizan intramuros o en casas de total confianza y tienen que ver con bordar, coser, pintar y enseñar diversas disciplinas (música, idiomas, dibujo). También con el cuidado general de niños y niñas como aya o institutriz, profesiones estas que adquieren gran importancia en la obra de Sinués conforme la toman en la propia sociedad española y que son perfectas a su juicio para la condición maternal de las mujeres: "Hoy ya hay institutrices españolas, pues la carrera está abierta y cada año toman algunas jóvenes un diploma honrosísimo, con el que pueden ganar su sustento y el de su familia, si es necesario" (1880: 37). 
Su asunción progresiva de los valores de la clase media hace que sus jóvenes trabajadoras se revistan de una dignidad que está casi al mismo nivel que la de la madre. Dado que en sus familias ha desaparecido la figura del pater, todas ellas mantienen vidas estrictas que incluyen no salir del hogar y no relacionarse con ningún varón en forma alguna que pueda dar lugar a equívocos sobre el origen de sus ingresos. Por ello, son especialmente recompensadas por la autora con matrimonios de corte pragmático: muchas de ellas acceden a casarse, aunque pueden mantenerse solas, por garantizarse una cierta tranquilidad y por la compañía, aunque no ocultan que no las arrebata la pasión y en muchos casos las uniones vienen favorecidas por la cortesía, el cariño y el respeto. También es frecuente que ambos miembros de la pareja cuenten con un primer amor tormentoso y quieran construir el matrimonio lejos de las pasiones y desde la complicidad en unos fines de clase. En este punto, una región de España sobresale en el aprovisionamiento de varones adecuados para el matrimonio de la joven de clase media: es en Cataluña donde Sinués ubica a varios de sus personajes masculinos, resaltando en ellos las cualidades regionales estereotipadas de respeto filial, dedicación al trabajo y ahorro meticuloso.

$M^{a}$ del Pilar Sinués no se propone como ejemplo de mujer independiente de una manera frontal, decantándose siempre por las profesiones derivadas de la educación de adorno que defiende. Eso no significa que no contemple la posibilidad de escribir sin dejar de ser virtuosa, pero no coloca la escritura como profesión deseable. Creo que esta ausencia de la literatura como oficio posible tiene que ver con su propia realidad y la condena social a la que ella misma fue sometida por la ruptura de su matrimonio. Es por esto por lo que, cuando recomienda la literatura a las mujeres, lo hace destinándolas a la producción para su propia familia y tras componer un modelo perfecto de esposa y madre que justifique el escribir:

Una joven bien educada puede, en el día de la desgracia, enseñar cosas buenas y agradables; puede ganar su vida y unirse al hombre que ama, aunque la fortuna de ese hombre sea modesta, porque puede ayudarle; una señorita cuya educación abrace el amor y el cuidado del hogar y el conocimiento perfecto de una de las manifestaciones del arte, puede educar a sus hijos y hasta escribir algunos libros que ayuden al bienestar de los suyos, porque la literatura va siendo ya lucrativa (1882: 291).
En todo caso, el trabajo de la mujer está siempre ligado a la excepcionalidad desafortunada y se concibe como una ayuda si se mantiene pasada la boda. Aunque Sinués cree matrimonios ficticios de jóvenes de la clase media que trabajan cada uno conforme a su sexo, la idea de que las labores femeninas son un complemento a las tareas masculinas es constante. De hecho, lo deseable es que conforme ese muchacho burgués ascienda en edad y méritos, aumente su caudal y la esposa pueda entonces dedicarse por entero al hogar y abandonar el trabajo remunerado.

La autora no escatima quejas hacia el sistema económico capitalista, sin percibir las estrechas relaciones de causa y efecto que se dan entre la ideología burguesa y la economía de mercado. En sus obras, distinguirá entonces lo que llama especulación honrada de la que se mueve por la pura codicia y es fuente de todos los males del siglo: "hay necesidad de improvisar recursos y de encontrar en la especulación el dinero que no da ni el patrimonio, ni tampoco el trabajo, ese otro patrimonio de la honradez y del decoro" (1876: 29). Las mujeres son las principales perjudicadas en una época que, en palabras de la autora, "por ser muy ambiciosa, es también muy egoísta" (1878: 207).

La ideología de género de $\mathrm{M}^{a}$ del Pilar Sinués se engloba así bajo la llamada estética de la resignación, proponiendo un modelo de conducta para las españolas de la clase media que les facilite la vida en un contexto social, económico e ideológico en el que se las destina a la maternidad y al rol de "Ángel del Hogar". Bajo un claro discurso de subordinación femenina al varón, se oculta un planteamiento pragmático de la vida de las mujeres, ya que la autora considera más sencillo para ellas adecuarse a lo que les pide el sistema a través de sus consejos que oponerse a él. La religión católica ofrece el marco de la resignación y sublima la función biológica de la maternidad como la misión fundamental de las mujeres, dándoles una superioridad moral que debe contentarlas de la obvia inferioridad en la que viven.

En este contexto económico de cambio de sistema hacia el capitalismo, se explican ciertas brechas dentro del discurso conservador de la escritora que tienen que ver con la educación y el empleo, pues contempla la necesidad de una formación para quien ha de ser educadora de su 
descendencia y la posibilidad de trabajar si las circunstancias dejan a las jóvenes sin varones proveedores. Las reclamaciones no tienen que ver con un derecho de las mujeres en tanto que individuos sino con la coyuntura del país y la más apremiante necesidad, por lo que se distingue claramente la posición de una conservadora como $\mathrm{M}^{\mathrm{a}}$ del Pilar Sinués de la que mantienen las autoras feministas del período como Rosario de Acuña o Concepción Arenal. De esa relación entre Sinués y el discurso de emancipación de las mujeres hablaré para cerrar este análisis de su obra.

\subsection{El temor al monstruo emancipado}

A lo largo de las muchas páginas que componen su producción pedagógica, $M^{\text {a }}$ del Pilar Sinués toma partido contra el feminismo de su época y ofrece argumentos desfavorables a la emancipación de las mujeres por considerar que esto atenta contra la religión, las costumbres y las altas misiones que son propias del sexo femenino. Aunque ella es una mujer sola que vive de su trabajo, por lo que podríamos considerarla materialmente emancipada, defiende el hogar, la maternidad y la crianza como escenarios deseables para las mujeres españolas.

En El ángel del hogar encontramos la primera muestra de su rechazo frontal al feminismo a través de una de las novelas que intercala en la obra y que está protagonizada por Alicia, una niña educada para ser una mujer libre. Me interesa detenerme en el personaje y en cómo $\mathrm{M}^{\mathrm{a}}$ del Pilar Sinués lo articula como un ser monstruoso en los términos en los que Michel Foucault analizó esta figura y su conceptualización en la literatura psiquiátrica y jurídica del siglo XIX.

Foucault analiza cómo de una cuestión fisiológica relacionada con la deformidad, el concepto se amplía al ámbito de lo moral conforme avanza el siglo XIX, entendiéndose que "hay monstruosidad donde el desorden de la ley natural toca, trastorna, inquieta el derecho, ya sea el derecho civil, el canónico o el religioso" (2001: 65). En esta clave se inserta el rechazo del feminismo de Sinués, quien considera que las mujeres que desean la emancipación o que actúan con libertad, están trastocando leyes divinas y sociales, hasta el extremo de que su personaje será una nueva Eva pecadora que, en su obstinación, hallará su propio final trágico.

Sinués califica los discursos de emancipación como "teorías de cabezas enfermas, que jamás se podrán practicar” (1859: 465). También define a las mujeres que piensan o actúan en término de mayor libertad como "anomalías de mi sexo" (1877: 351), además de abundar - como veremos en el análisis de la historia de Alicia- en el desaliño estereotipado de las mujeres que se salen de la norma. No le preocupa sólo lo religioso, sus textos dejan traslucir una inquietud social relacionada con la mentalidad burguesa y la utilidad derivada de la separación sexual del mundo en distintas esferas de actuación. Así, Sinués escribe que "si por crear sabios y bachilleres con faldas dejamos el hogar sin la madre y la esposa, la sociedad no ganará en el cambio" (1882: 293)

Foucault analiza la manera en que del gran monstruo, de la imagen del terror y lo prohibido, se pasa a lo largo del siglo a versiones más familiares de este estereotipo de la época: casi cualquier conducta considerada impropia - especialmente las sexuales-deviene en patología y, todo aquello que contravenga la norma será censurado como anormal, desviado, de forma que la desactivación y desacreditación de las demandas feministas ${ }^{12}$ no se produce desde una argumentación lógica, de ideas, sino invocando el carácter desnaturalizado de las mujeres que se atreven a considerar meramente posible su independencia o su condición de ciudadanas. En las citas de Sinués se emplean palabras como "enfermedad" o "anomalía" precisamente porque la autora interpreta el feminismo en clave moral pero también natural, fisiológica.

Si la sociedad del siglo XIX estableció mecanismos de control, tecnologías en términos de Foucault, que fueron ciñendo la vida de las personas catalogadas como anormales, como monstruosas, en la novelística de Pilar Sinués hallamos un vivo ejemplo de esto, en tanto que sus madres educadoras cumplen a la perfección el cometido de intentar corregir a sus hijas desviadas, del mismo modo que para Foucault se establecen pasos

${ }^{12}$ No en vano, Susan Kirkpatrick ha señalado que "la abundancia y variedad de representaciones misóginas de la mujer que aparecieron en este período [fin de siglo XIX] expresan la ansiedad masculina derivada de la nueva conciencia de la inestabilidad del género" (2003: 86) 
muy precisos para enderezar las conductas monstruosas que pueblan la literatura y el imaginario de finales de siglo (2001: 60).

En la breve novela antifeminista de Sinués, ambas tendencias están en liza: por un lado, la condición libre y por tanto anormal de Alicia; por otro, el empeño constante de su madre por educarla en los términos de moral católica y virtud burguesa que son propios de las españolas y con los que aspira a dar a su hija herramientas con las que modificar - corregir - su carácter. Como se verá a continuación, ninguna de las dos saldrá victoriosa del empeño.

La trama se inicia con el matrimonio de la madre de Alicia, la española Rafaela, con el banquero inglés Ricardo W., en una unión aceptada por la joven para salvar de la ruina económica a su padre. El banquero espera una compañera en el trabajo en términos anglosajones y se encuentra a una mujer ignorante que no tiene ninguna instrucción a pesar de tener un talento y un sentido común poco frecuentes. Cuando nace su hija, el banquero decide separarla de su madre para educarla como mujer emancipada, evitando la mala influencia de la bondad y el amor materno de Rafaela. Su hija tiene desde niña diversos maestros que le enseñan disciplinas alejadas de la educación de adorno que en el mejor de los casos podía esperar una mujer. Su padre incentiva en la niña el culto al dinero: el fin último del deseo de emancipación tiene que ver con que su fortuna familiar pase a su hija y ésta, educada sin sentir el amor y para ser autosuficiente, la conserve hasta la muerte en su poder.

La familia se traslada a París y Ricardo W. proyecta culminar el plan educativo de su hija haciendo que su socio Claudio Laroche, malvado Dorian Gray avant la lettre, se lleve a Alicia a Estados Unidos, único país donde la mujer está supuestamente liberada. Allí la niña deberá asistir a mítines y clases universitarias impartidos por mujeres, deberá ver cada día la crueldad con la que se trata a los negros esclavos y, todavía más importante, deberá conocer la bajeza moral y la perversión de Laroche para así convencerse de que no se puede confiar en las personas ni en los sentimientos. Aunque Claudio no acepta el encargo por parecerle perverso, el proceso educativo de Alicia no se tuerce y ella, al fallecimiento de su padre y ya en Madrid, es un portento que escandaliza a la sociedad española al vivir como una viuda o una soltera y administrar su dinero y sus negocios en absoluta soledad.

Sin embargo, además de avara como su padre, la joven es desconfiada por falta de una buena educación afectiva, lo que le hace tomar malas decisiones de negocios que le llevan a verse en apuros económicos. De forma inexplicable en el transcurrir de la trama, Alicia cambia de opinión y se persuade de que nada puede una mujer sola, por lo que decide casarse invirtiendo el último capital que le queda de su madre. Pero como ha sido criada sin afectos y no ha aprovechado ninguna de las ocasiones de redención que la trama le ha presentado, escoge mal a su pretendiente, que resulta ser un joven descrito en términos de afeminamiento que huye a los dos días de casados dejándola en la ruina. Alicia, finalmente, decide suicidarse.

Por contraposición, otros personajes de la trama consiguen ser felices al haber cumplido adecuadamente las pautas que Sinués prescribe para cada sexo: Consuelo, la angelical y buena amiga de Alicia, acaba casada con un redimido Laroche que deja atrás su pasado inmoral para dedicarse a "especulaciones honrosas" con las que convertirse en un hombre respetable, viviendo en armonía con su esposa e hijos, educados ellos como probos hombres públicos y su única hija, en los términos de bondad, industria, ahorro y recato de su madre.

Podemos analizar entonces cómo se construye la figura monstruosa de la mujer emancipada a través de Alicia atendiendo a cómo Pilar Sinués articula los estereotipos culturales propios de cada nación, jugando con una idea que defenderá a lo largo de toda su obra según la cual la mujer española tiene un destino natural por imperativo divino que en nada tiene que ver con lo que conviene a las francesas, alemanas o inglesas. Así, de un lado queda la mujer española ideal: buena hija, buena esposa, buena madre y la mujer emancipada, que sigue modelos anglosajones y en todo resulta un monstruo que, desde la óptica de Sinués, usurpa y deturpa las funciones sociales masculinas al abandonar la misión divina de su sexo. La autora proyecta así no sólo los estereotipos habituales sobre la feminista, sino también sobre la nación en la que supuestamente se ha establecido poco menos que un reino de las mujeres. Ricardo W. expresa en los siguientes 
términos su deseo de enviar a la niña a Norteamérica (365):

Quiero, continuó el banquero, que Alicia asista a las disertaciones de las doctoras, y a las cátedras de los protestantes; quiero que la lleves todos los días al mercado de esclavos, y que presencie los castigos que los colonos imponen a sus negros ${ }^{13}$; de esta manera perderá esa blandura de carácter que aun advierto en ella, y que le ha sido fatalmente transmitida por su madre.

Dado que los saltos de espacio y tiempo de la trama no están precisamente logrados, tampoco ha de extrañarnos que el proyecto de corromper a Alicia en los Estados Unidos no se lleve a término. Resulta incoherente que el banquero no lo concluya y se olvide de él, pero en todo caso su hija es en sí una mujer anglosajona que acaba representando todos los contravalores que Sinués atribuye a las defensoras de la emancipación femenina, especialmente si además la encarnan. Por lo tanto, sin llegar a cruzar el Océano Atlántico, Alicia se ha acabado convirtiendo en aquello que su padre deseaba con su educación y es descrita en los términos que a continuación referiré.

La joven es muy hermosa, como su madre, pero irá perdiendo progresivamente su belleza al ser una mujer intelectual y por lo tanto, varonil. Cuando la encontramos en París, recién terminada su intensa jornada de estudio, la autora la describe de la siguiente manera (342):

Contaba solo diez primaveras, y su estatura y la gravedad de sus facciones acusaban catorce.

Grandes ojeras daban a su mirada, azul y abrillantada, una expresión muy triste.

Sus espesas cejas negras, sedosas y afelpadas, y sus luengas y espesas pestañas, negras también, prestaban cierta austeridad y dureza a la parte superior de su rostro, que completaba el corte de su ancha frente, elevada y serena, y en la cual estaba escrita su inteligencia grandiosa, rápida y profunda.

${ }^{13}$ No deja de resultar paradójico que, como ejercicio de crueldad, Míster W. desee que su hija presencie la brutalidad con que se trata a los esclavos, sobre todo si tenemos en cuenta la estrecha relación entre la militancia sufragista y la anti esclavista de muchas feministas norteamericanas; asociación esta a la que no fue ajena España en la pluma de la gran poeta romántica Gertrudis Gómez de Avellaneda, cuya novela Sab trata precisamente de forma trágica el tema del amor interracial e interclasista en Cuba, lugar de nacimiento de la autora.

[...] Conocíase que el estudio incesante y devorador, que la ambición de saber habían petrificado el corazón de aquella hermosa niña, y que la gravedad de las meditaciones había contenido las expansiones de su carácter.

Ya en Madrid, la niña llega a cortarse el pelo, pareciendo enteramente un muchacho, porque le parece una pérdida de tiempo el empleado en peinarse a diario (422). Cuando al final de la historia Sinués cuenta cómo ve pasar su carruaje, la describe así (459):

[...] era una señora que aparentaba sesenta años de edad, en extremo flaca $\mathrm{y}$ angulosa, de nariz larga, boca hundida y ojos azules y mortecinos.

$[\ldots]$

- Solo tiene cuarenta y seis años: mas la sequedad del corazón envejece el rostro, mi amada María, y eso es lo que ha acontecido a esa mujer. $[\ldots]$

- Cegada por su vanidad, cree que es aún muy bella, y que su talento y su mérito son superiores a la juventud misma.

La fisonomía de Alicia recuerda en su descripción a la de su padre, de manera que queda clara la transformación en ella desde su gracilidad y belleza infantiles hasta la monstruosidad de su condición libre, más acuciada cuanta menos influencia ejerce su madre en ella. A esta transformación física se unen unos rasgos de carácter en los que sobresalen la avaricia y la soberbia. La primera le viene dada por la educación para la usura que recibió de su progenitor; la segunda, por su inteligencia. En efecto, Alicia ha llegado a creer que es autosuficiente por lo vasto de su instrucción y adorna ésta con la vanidad: disfruta del lujo, de la ostentación de su poder y de los elogios y el asombro del mundo. Al no conocer el amor, es insensible y, por tanto, cruel: dispensa a las clases inferiores (servicio doméstico, empleados) un trato inhumano que no hará sino acrecentarse cuando muera su madre. Entonces, sin el referente familiar más importante que ha tenido, $M^{a}$ del Pilar Sinués considerará la expresión máxima de su crueldad la costumbre de desahuciar de sus inmuebles a quienes no pueden pagar o se atrasan con las cuotas.

Aunque constantemente rodeada por otras personas, Alicia está sola. Ya su madre había pronosticado tal condición al considerar que la inteligencia de su hija haría que ningún hombre quisiera amarla (344): 
Siendo tú tan grande, ¡qué hallarás que sea digno de ti! ¡Qué habrá en el mundo que no te parezca inferior! ¡Qué hombre habrá que puedas tú respetar por la superioridad de tu inteligencia, o por lo vasto de tu instrucción! ¡Oh, hija mía! ¡Tu madre ha sido desgraciada por ser muy ignorante, pero tú vas a serlo más por saber demasiado!

En el fondo, la defensa del término medio que es habitual en toda la obra de Sinués y que, como señalé, es uno de los rasgos políticos del moderantismo hispano tal cual lo analizó José Luis Aranguren, opera aquí cuando la autora lleva adelante su trama y acaba con casi todos los personajes extremos, dejando nada más la felicidad para la joven Consuelo, capaz de sobreponerse a las penurias, y para Laroche, redimido por la autora que no deja de mostrar hacia ese hombre temperamental metido a ejemplar ciudadano una gran simpatía. Alicia por unas razones, su madre por otras, terminarán muertas y lo harán en un doble sentido: para la primera será un castigo que además es pecado al cometer suicidio; para la segunda la muerte será el descanso y la redención que Dios reserva en el mundo de Pilar Sinués a los sufridos ángeles domésticos.

El final de la protagonista es tan trágico porque es una mujer desnaturalizada, tanto más cuanto que no es capaz de sentir amor ni siquiera por su madre. En la negación de ese vínculo, Sinués cifra la ruina de la joven. Si bien durante toda la historia se nos ha dicho que Alicia profesa hacia su madre un cariño inexplicable, en el que no falta la lástima, para el final de la historia, ésta confiesa a Consuelo que la única vez que ha llorado ha sido al ver morir a su madre y no precisamente por amor (453):

- ¿Pero, de qué nacía ese sentimiento?

-De la certidumbre de haber perdido al único ser que me era completamente adicto en la tierra.

— ¡Ah! exclamó Consuelo con vehemencia: ¡he aquí los tristes resultados del saber! ¡Sólo con un temple como este, puede vivir la mujer emancipada! Como Eva, has trocado el amargo fruto del árbol de la ciencia, por la obediencia y el amor a Dios.

Con la alusión a Eva se reafirman a la vez su carácter demoníaco y la condición antinatural de la emancipación de las mujeres. Evocando el orden impuesto por la divinidad católica, Sinués convierte el final de Alicia y su solución del conflicto en algo inmutable y justo cual apocalipsis. Ya había anticipado su padre que deseaba para su hija las cátedras de los protestantes, cuyo Dios es ajeno al católico y, por tanto, desviado en el recto control de las funciones sociales de sus hijas.

A lo largo de toda la historia, Sinués construye así un modelo de género y de nación que le sirve para justificar su defensa del estereotipo burgués del ángel doméstico como el ideal para las mujeres españolas. Los valores religiosos, morales y culturales se confrontan hasta ofrecer dos imágenes: del frío pragmatismo y cálculo anglosajón sólo puede nacer la desconfianza y la avaricia, que conducirá a la muerte de Alicia pues el carácter individualista, emancipado, de ésta le impedirá modificar su conducta en el relato para obtener la salvación. Por otro lado, de la bondad y la fe de su amiga Consuelo, capaz de redimir incluso al hombre perdido, se obtiene un modelo de familia burguesa en la que reina la armonía y que tras grandes esfuerzos de ambos cónyuges termina por obtener el éxito económico y social.

Todo lo que $\mathrm{M}^{\mathrm{a}}$ del Pilar Sinués dice de las mujeres emancipadas o de la situación real de la población femenina en Estados Unidos es una ficción interesada: para los años anteriores a 1858 las estadounidenses no contaban con los beneficios y libertades "varoniles" achacados por la autora zaragozana pero, en el plano de lo real, sí sufrían los insultos y descalificaciones que Sinués vierte en forma de tópicos sobre el desaliño, la fealdad o la dureza de corazón de las feministas. La ferocidad del ataque sirve a la vez para demostrar lo presente que estaba en el debate público español la cuestión femenina. Y no ya en los términos en que se plantea a lo largo del siglo XVIII, sino en un punto de desarrollo político y teórico mucho mayor en el que se pide una emancipación que puede poner por tierra la estructura de las sociedades conforme se conocían hasta entonces.

Si seguimos la cronología de sus obras, leemos un razonamiento igualmente contrario a la emancipación quince años después de publicarse El ángel del hogar: "No pertenezco yo al número de las que creen que las mujeres debemos legislar en los congresos y dictar sentencias en los tribunales; sino que antes bien, me parece que la misión de la mujer debe ser realizada en el interior del hogar doméstico" (1876: 5). Este libro, en el que 
habla especialmente de los deseos de independencia de las mujeres, ofrece una defensa radical de los presupuestos conservadores y de su propia ideología resignada, pues si es cierto que la dependencia puede verse como un yugo para la mujer, también le sirve de protección y amparo ante el mundo, siendo grandes los peligros si se termina con ella (1876: 39).

Sinués afirma sentir lástima ante las defensoras de la emancipación femenina: “ ¿Para qué quiere la mujer vivir por sí sola? Tal como vive hoy tiene ancha esfera donde moverse y donde lucir santas y adorables virtudes: y lejos de separarla del hombre, convendría educarla para que viviese a su lado y para que fuese lo que debe ser" (1876: 153). En 1877 escribe que la independencia y la libertad de la mujer se consiguen cuando ésta se convierte en verdadera compañera del hombre, estableciendo una relación en los términos descritos en su obra (346). No duda, además, en perseverar en la difusión de estereotipos sobre las feministas muy arraigados en la época, consistentes en atacarlas por su mala gestión del hogar y de su imagen:

Casi todas las mujeres instruidas son desaseadas y olvidadizas del bien parecer: viviendo en una región muy distante de lo que ellas llaman pequeñeces de la vida, desdeñan el decoro, la limpieza, el primor y la coquetería que es el mejor ornato y el arma más bella de nuestro sexo: la mujer bien educada cuida mucho de esas pequeñeces (1877: 366).

Al paso de los años, mientras el ideario feminista se hace más amplio, Sinués abarca más temas en su crítica. Para la década de 1880 su obra incluye varias alusiones al sufragio femenino:

No quiero hablar de las mujeres que votan, porque no sabría hacerlo: hasta tal extremo desconozco el asunto, y cuál es el mal o el bien que puede redundar a la sociedad de esa manifestación de fortaleza y de importancia política que parece estima mucho la más débil mitad del género humano (1882: 82).

Al tiempo, seguirá escribiendo sobre el feminismo con base en estereotipos, ejemplificando los desastres que para las mujeres supone el querer ser celebridades, desastres que se concretan en el aislamiento social y en la condena del mundo.

Sus opiniones aparecen también en las revistas y periódicos en los que colabora al compás, como he dicho, del ritmo de los debates en la sociedad. El artículo "La instrucción de la mujer" que reproduce en Verdades dulces y amargas (1882), es una supuesta reflexión al hilo de las cartas que diversos padres de familia le han dirigido pidiéndole opinión sobre el asunto. En este texto expondrá su ideario educativo ya visto: es preciso que las mujeres tengan una cierta instrucción útil, relacionada con sus funciones maternales, pero sobre todo que tengan claros los valores de bondad y belleza que han de guiar su labor doméstica. Mientras autoras como Emilia Pardo Bazán o Concepción Arenal reclaman una total libertad en la elección de estudios para las mujeres, ella defenderá a capa y espada esa educación de adorno que, a su juicio, es totalmente utilitaria pero que el feminismo no dejará de condenar en España hasta bien entrado el siglo XX.

La ideología de $\mathrm{M}^{\mathrm{a}}$ del Pilar Sinués se inserta en el discurso hegemónico de la burguesía capitalista, entronizando a las mujeres como ángeles domésticos que en el seno del hogar aseguran con su labor no reconocida la reproducción y producción sociales. Sus mínimas demandas aperturistas tienen que ver con su propia clase y con paliar los efectos de un capitalismo inducido por ella, pero al no considerar que las mujeres son sujetos individuales al margen de su biología y de la religión, su postura y la del feminismo son irreconciliables. Todo ello, insisto, a pesar de su forma de vida: trabajando para salir adelante, sin un hombre del que depender y con una carrera literaria de éxito.

\section{Conclusiones: domesticar la escritura}

El objetivo de este artículo era estudiar el modelo de conducta para las españolas de las clases medias que propone $\mathrm{M}^{\mathrm{a}}$ del Pilar Sinués, en relación con el propio estatus de la escritora como mujer de letras. El punto de partida de este análisis era la paradoja existente entre la ideología difundida y la realidad personal de la autora: mientras que postula la vida doméstica atada a las funciones reproductivas-biológicas, ella goza de una cierta libertad de movimientos en la esfera pública tras haber visto legitimada su posición por difundir, precisamente, el modelo de mujer de su casa entre las lectoras. $\mathrm{M}^{\text {a }}$ del Pilar Sinués sobresale entre las autoras que practicaron esta narrativa y literatura de adoctrinamiento en tanto en cuanto fue la 
de más éxito en vida, la más prolífica y la que mejor supo adaptarse a las modas del siglo, permitiéndose rupturas con los estrechos moldes de la domesticidad en su producción narrativa. Eso no impide la contradicción entre vida y discurso que caracteriza a muchas de las pioneras en el campo literario.

En su caso, el conflicto se articula en torno a lo que se puede y lo que se debe expresar para acceder al ámbito cultural de la esfera pública y mantenerse en él con una cierta dignidad personal, sin sufrir graves ataques por ello. La escritora puede pensar lo que quiera pero no decirlo o escribirlo. La formulación textual de esa norma básica de integración en la sociedad literaria del siglo XIX nos acerca a la mujer real que se esconde tras las máscaras de consejera doméstica y amiga de las mujeres. Sus palabras, junto con sus decisiones textuales en la producción pedagógica (la que le da sustento a su identidad como escritora) nos dejan intuir la estrategia de legitimidad, no coincidente con un verdadero deseo u opinión al respecto del mundo.

Sinués actúa textualmente como ángel doméstico para respaldar no sólo su obra pedagógica sino su derecho general a tomar la palabra pública. Resulta complicado, pues, acceder a una opinión de sí real porque incluso en estos textos (o precisamente en este tipo de textos) la autora debe revelarse como moralista, consejera y amiga. Primero por un desinterés solidario con su género, finalmente dejando claro que ella es única en su condición y ha realizado una gran labor equiparable a la de grandes nombres de la literatura francesa inmediatamente anterior. Sus prólogos son una metaficción en la que ella interactúa a su vez con lectoras ideales, compartiendo el interés por historias que, no olvidemos, presenta siempre como realidad, como hechos positivos ejemplares que ella relata a mayor gloria y beneficio de sus congéneres.

Y aunque en su producción puramente narrativa la escritora ignora sin titubear sus propias recomendaciones, no puede evitar prólogos autojustificativos en los términos de la domesticidad que le ha permitido el acceso a la palabra pública y que es su escudo ante los ataques que recibe primero por el mero hecho de tomar la pluma, segundo por hacerlo mal, ya que la generalidad de sus contemporáneos y de los escritores más jóvenes 
introducción y creo haber demostrado a lo largo de estas páginas, es especialmente relevante porque permite estudiar estos cambios sociales en un momento trascendental en la historia española: a través de sus consejos, reconvenciones y temores intuimos un escenario en el que la burguesía se está haciendo con el poder económico (paulatinamente acaparará también el político) e imponiendo sus valores y su visión del mundo al conjunto de la población, poniendo especial énfasis en el control de los cuerpos y de la sexualidad de las mujeres. En este contexto, los manuales pedagógicos que moldean la conducta ideal de las jóvenes son muy útiles al sistema y se apoyan en toda una industria editorial que ha experimentado un cambio significativo en el sexo de su público. Las revistas, los manuales, la moda y las novelas articulan el ideal femenino burgués y constriñen la libertad y la acción de las mujeres reales que intuimos en los resquicios de la obra de Sinués.

La Modernidad como etapa histórica tiene entre sus procesos fundamentales el haber estructurado el mundo separando a las personas por su sexo biológico mediante la atribución de funciones diferentes y desiguales sustentadas, precisamente, en una interpretación intencionada de la biología. En el momento presente, a pesar de todos los procesos deconstructivos que podemos llevar a cabo en el plano intelectual y de los avances que algunos países han conquistado en el plano de lo social, seguimos viviendo en función de sólidos esquemas sexistas apuntalados en el mundo occidental a lo largo del siglo XIX. Su asunción sólo puede combatirse desde la lectura crítica de los textos que, en cada tradición, han ido consolidando esta ideología.

Por otro lado, la figura de Sinués como escritora sigue diciéndonos mucho al respecto de la presencia de las mujeres en el campo literario ya que, aferrándose a una tipología de textos que le dan legitimidad autorial, intenta indagar en otras vías y cumplir una vocación manifestada desde el primer momento como motor principal de sus acciones. No se ha analizado de forma fría, lejos de lo folletinesco, hasta qué punto es revelador el que la joven Sinués se aferrara a una declaración de amor y petición matrimonial por carta para salir de Zaragoza y presentarse en Madrid, obteniendo mucha independencia para llevar a cabo sus aspiraciones literarias. Que su matrimonio fracase, dada la manera en que se produjo, parecería lo normal.

Pero, salvo por cierta censura social, para ella la separación no es totalmente negativa: si el amor era la excusa para abandonar la tutela familiar y la vida provinciana, la llave para el Madrid de la literatura, entonces cumplió su función y le permitió después desarrollar su vida hasta cierto punto como quiso, como escritora. El peaje ha quedado claro: la vía de lo doméstico, no siempre hablar o escribir lo que libremente se piensa. No es mi intención cerrar estas páginas con una traslación a situaciones de la segunda mitad del siglo XX pero sí apuntar que la domesticación de la escritura que permitió el ejercicio de la misma a las mujeres a lo largo del siglo XIX, no es ajena a otros procesos -también mercantiles y legitimadores-, que rigen modas literarias y actitudes en la actualidad.

Me gustaría pensar que si somos capaces de ver los resquicios de estos edificios de moralidad decimonónica construidos por las autoras, seremos capaces de derrumbar las consecuencias reales, educativas, represoras, que esas ideas han tenido en las mujeres de carne y hueso desde entonces. Señalando la actuación y el disfraz que permite el juego público de la literatura, será posible tal vez relativizar el alcance ideológico, la legitimidad moral, de las ideas que todavía hoy nos codifican como seres biológicos y estereotipados, imposibilitadas para una verdadera libertad.

Recibido: 04/03/2013

Aceptado: 26/06/2013

\section{Referencias Bibliográficas}

Aguado, Ana (2003), «Género y ciudadanía en la formación de la sociedad burguesa», Arenal 10:1, pp. 61-79.

Aranguren, José Luis (1982), Moral y sociedad. La moral española en el siglo XIX, $1^{\text {a }}$ ed. 1966, Madrid: Taurus.

Armstrong, Nancy (1991), Deseo y ficción doméstica. Una historia política de la novela, Madrid: Cátedra. 
Blanco, Alda (2001), Escritoras virtuosas: narradoras de la domesticidad en la España isabelina, Granada: Universidad de Granada.

Blanco García, Francisco (1889), La literatura española en el siglo XIX. Parte primera, Madrid: Saénz de Jubera Hermanos, Editores.

Bleiberg, Germán (1979), Diccionario de historia de España, Madrid: Alianza Editorial.

Bridget, Aldaraca (1992), El ángel del hogar: Galdós y la ideología de la domesticidad en España, Madrid: Visor.

Burdiel, Isabel (2010), Isabel II o el laberinto del poder, Madrid: Taurus.

Campos Palacio, Lola (2001), Mujeres aragonesas, Zaragoza: Ibercaja. Obra social y cultural.

Cejador y Frauca, Julio (1915), Historia de la lengua y la literatura castellana VIII, Madrid: Tipografía de la Revista de Archivos, Bibliotecas y Museos.

Charnon-Deutsch, Lou (1994), Narratives of desire. Nineteenth-Century Spanish Fiction by Women, Pennsylvania: The Pennsylvania State University Press.

Criado y Domínguez, Juan P. (1889), Literatas españolas del siglo XIX. Apuntes bibliográficos, Madrid: Imprenta de Antonio Pérez Dubrull.

Denby, David J. (1994), Sentimental Narrative and the Social Order in France, 1760-1820, Cambridge: Cambridge University Press.

Ezquerra del Bayo, Joaquín (1924), Retratos de mujeres españolas del siglo XIX, Madrid: s.e.

Foucault, Michel (2001), Los anormales. Curso del Collège de France (19741975), Madrid: Akal.

Fraisse, Geneviève y Michelle Perrot, dir. (2006), Historia de las mujeres IV. El siglo XIX, Madrid: Taurus.

González-Blanco, Andrés (1909), Historia de la novela en España: desde el Romanticismo a nuestros días, Madrid: Sáenz de Jubera Hermanos, Editores.

Hartzenbusch, Eugenio (1894), Apuntes para un catálogo de periódicos ma- drileños desde el año 1661 a 1870, Madrid: Establecimiento Tipográfico «Sucesores de Rivadeneyra».

Hibbs-Lissorgues, Solange (2008), «Escritoras españolas entre el deber y el deseo: Faustina Sáez de Melgar (1834-1895), Pilar Sinués de Marco (18351893) y Antonia Rodríguez de Ureta», en Pura Fernández y Marie-Linda Ortega eds., La mujer de letras o la "letraherida": discursos y representaciones sobre la mujer escritora en el siglo XIX, Madrid: CSIC, pp. 325-343.

Jiménez Morell, Inmaculada (1992), La prensa femenina en España (desde sus orígenes a 1868), Madrid: Ediciones de la Torre.

Kirkpatrick, Susan (1991), Las románticas. Escritoras y subjetividad en España, 1835-1850, Madrid: Cátedra.

Lewis, Linda M. (2003), Germaine de Staël, George Sand and the Victorian Woman Artist, Columbia \& London: University of Missouri Press.

Navales, Ana María (1999), «María del Pilar Sinués, escritora zaragozana del siglo XIX», Oscura turba de los más raros escritor españoles, Zaragoza: Xordica, pp. 217-227.

Nombela, Julio (1976), Impresiones y recuerdos, Madrid: Tebas.

Pageard, Robert (1990), Bécquer: leyenda y realidad, Madrid: Espasa-Calpe.

Perrot, Michelle (1992), "Formas de habitación», Historia de la vida privada. Sociedad burguesa: aspectos concretos de la vida privada, dir. Philippe Ariès y Georges Duby, Madrid: Taurus, pp. 313-330.

Quintana, Manuel José (1969), Poesías completas, ed. Albert Derozies. Madrid: Castalia.

Rabaté, Colette (2006), «Les espagnoles créatrices dans la presse à l'époque d'Isabelle II (1833-1868)», Regards sur les espagonles créatrices XVIIIe-XXe siècle, dir. Françoise Étienvre, Paris: Presses Sorbonne Nouvelle, pp. 93106.

--- (2007), ¿Eva o María? Ser mujer en la época isabelina (1833-1868), Salamanca: Universidad Salamanca.

Rivière Gómez, Aurora (1993), La educación de la mujer en el Madrid de 
Isabel II, Madrid: Horas y Horas.

Rueda, Ana (2001), Cartas sin lacrar. La novela epistolar y la España ilustrada 1789-1840, Madrid: Iberoamericana / Vervuert.

Sánchez Llama, Íñigo (2000), Galería de escritoras isabelinas. La prensa periódica entre 1833 y 1895, Madrid: Cátedra.

---- (2001), Antología de la prensa periódica isabelina escrita por mujeres (1843-1894), Cádiz: Publicaciones de la Universidad de Cádiz.

Scanlon, Geraldine (1986), La polémica feminista en la España contemporánea (1868-1974), Madrid: Akal.

Segovia, Ángel María (1876), Melonar de Madrid. Semblanzas, bocetos, caricaturas, retratos, fotografías, Madrid: A. Florenceano.

Simón Palmer, Ma del Carmen (1983), «Escritoras españolas del siglo XIX o el miedo a la marginación», Anales de literatura española 2, pp. 477-490.

---- (1991), Escritoras españolas del siglo XIX. Manual bio-bibliográfico, Madrid: Castalia.

---- (1997), «Cuerpo pensado, cuerpo vivido. Normas y transgresiones en la España del siglo XIX», Arenal 4:1, pp. 39-57.

---- (2008), «Vivir de la literatura. Los inicios de la escritora profesional», La mujer de letras o la letraherida. Textos y representaciones sobre la mujer escritora en el siglo XIX, eds. Pura Fernández y Marie-Linda Ortega, Madrid: CSIC, pp. 389-407.

Sinués, $\mathrm{M}^{\mathrm{a}}$ del Pilar (1859), El ángel del hogar. Obra moral y recreativa dedicada a la mujer, Madrid: Imprenta y Estereotipia española de los Señores Nieto y compañía.

--- (1860), Flores del alma. Poesías, Barcelona: Establecimiento tipográfico de Narciso Ramírez.

--- (1861), Fausta Sorel, Madrid: Nieto y Compañía.

--- $\left(1876^{2}\right)$, Un libro para las damas. Estudios acerca de la educación de la mujer, Madrid: A. de Carlos e Hijo, Editores.

--- (1877), Un libro para las madres, Madrid: Oficinas de La moda elegante ilustrada.

---- $\left(1877^{2}\right)$, Hija, esposa y madre. Cartas dirigidas a la mujer acerca de sus deberes para con la familia y la sociedad, Madrid: Oficinas de La moda elegante ilustrada.

---- (1878), La mujer en nuestros días (Obra dedicada a las madres y a las hijas de familia), Madrid: Agustín Jubera.

---- (1879), Un libro para las jóvenes. Estudio social, Madrid: Establecimiento tipográfico de M. P. Montoya y Compañía.

--- (1880), La dama elegante. Manual práctico y completísimo del buen tono y del buen orden doméstico, Madrid: Librería de A. de San Martín.

--- (1882), Verdades dulces y amargas. Páginas para la mujer, Madrid: Imprenta y fundición de la Viuda e Hijos de J. A. García.

--- (1884), La vida real: alegrías y tristezas de una familia, estudio social, Madrid: Imprenta y Fundición de los Hijos de García.

Urruela, María Cristina (2005), «El “ángel del hogar”: María del Pilar Sinués y la cuestión de la mujer», Literatura y feminismo en España, ed. Llisa Wollendorf, Barcelona: Icaria, pp. 155-169. 